\title{
The Emerging Functions of Circular RNAs in Bladder Cancer
}

\author{
Kai Sun ${ }^{1,+}+\mathbb{D}$, Di Wang ${ }^{1,+}$, Burton B. Yang ${ }^{2, *}$ and Jian Ma ${ }^{1, *}$ \\ 1 Urology Department, The Affiliated Yantai Yuhuangding Hospital of Qingdao University, \\ Yantai 264000, Shandong, China; 2019026330@qdu.edu.cn (K.S.); 2020026276@qdu.edu.cn (D.W.) \\ 2 Department of Laboratory Medicine and Pathobiology, Sunnybrook Research Institute, University of Toronto, \\ Research Building, 2075 Bayview Avenue, Toronto, ON M4N 3M5, Canada \\ * Correspondence: byang@sri.utoronto.ca (B.B.Y.); jma1980@126.com (J.M.); Tel./Fax: +86-0535-6695579 (J.M.) \\ + Kai Sun and Di Wang contributed equally to this work.
}

check for

updates

Citation: Sun, K.; Wang, D.; Yang, B.B.; Ma, J. The Emerging Functions of Circular RNAs in Bladder Cancer. Cancers 2021, 13, 4618. https:// doi.org/10.3390/cancers13184618

Academic Editor: Christos K. Kontos

Received: 16 August 2021

Accepted: 10 September 2021

Published: 15 September 2021

Publisher's Note: MDPI stays neutral with regard to jurisdictional claims in published maps and institutional affiliations.
Simple Summary: The role of circular RNAs has made breakthroughs in understanding the mechanisms of tumor development. Bladder cancer has an increasing incidence, high recurrence rate, high metastatic potential, poor prognosis, and susceptibility to chemotherapy resistance. Thus, it is essential to identify molecules related to the tumorigenesis of bladder cancer. In this review, we summarize current knowledge about the expression of circular RNAs in bladder cancer and their implications in vesical carcinogenesis. We further discuss the limitations of existing studies and provide an outlook for future studies in the hopes of better revealing the association between circular RNAs and bladder cancer.

Abstract: Bladder cancer (BC) is among the top ten most common cancer types worldwide and is a serious threat to human health. Circular RNAs (circRNAs) are a new class of non-coding RNAs generated by covalently closed loops through back-splicing. As an emerging research hotspot, circRNAs have attracted considerable attention due to their high conservation, stability, abundance, and specificity of tissue development. Accumulating evidence has revealed different form of circRNAs are closely related to the malignant phenotype, prognosis and chemotherapy resistance of $\mathrm{BC}$, suggesting that different circRNAs may be promising biomarkers and have therapeutic significance in $\mathrm{BC}$. The intention of this review is to summarize the mechanisms of circRNA-mediated BC progression and their diagnostic and prognostic value as biomarkers, as well as to further explore their roles in chemotherapy resistance.

Keywords: circular RNA; bladder cancer; biomarker; signaling pathways; drug resistance

\section{Introduction}

Bladder cancer (BC) is reported to be the 10th most prevalent human malignancy worldwide, with an estimated 400,000 new cases diagnosed and more than 165,000 deaths annually [1-3].Currently, new technologies are being developed to improve the detection of $\mathrm{BC}$, and new treatment options are being offered in the guidelines [4,5].The first-line treatment for BC is surgical section. In addition to traditional surgery, as well as chemotherapy and radiation, immunotherapy has been applied to treat BC patients [6,7]. However, including after radical cystectomy, distant metastases still exist in certain patients [4]. For advanced or metastatic BC patients, chemotherapy with cisplatin is the first-line treatment, and the efficacy is limited by chemotherapy resistance [8,9]. Tumor recurrence, metastasis and resistance to chemotherapy drugs make the overall therapeutic effects unsatisfactory, with a low five-year survival rate $[10,11]$. Appropriate molecular biomarkers can provide accurate information for $\mathrm{BC}$ staging to improve its early diagnosis and treatment efficacy. The molecular biological mechanisms underlying the tumorigenesis, progression, and chemoresistance of $\mathrm{BC}$ have attracted extensive attention from researchers, and new BC-related biomarkers are critical to improve the diagnosis and prognosis of $\mathrm{BC}$ patients [12-14]. 
$\mathrm{BC}$ tumorigenesis is a complicated process involving genetic mutations and dysregulation of epigenetic pathways. Epigenetic changes in BC, such as non-coding RNAs (NcRNAs) [15], DNA methylation [16], and histone modifications [17], have been extensively studied. Numerous ncRNAs have been demonstrated to participate in tumor initiation and progression. Therefore, an emerging field of clinical research is to explore the feasibility of targeting ncRNAs.

Circular RNAs (circRNAs) are single-stranded, closed-loop structures lacking $5^{\prime}$ caps and $3^{\prime}$ tails of linear RNA, which enable them to resist the degradation of Ribonuclease $\mathrm{R}$ (RNase R) and thus are more stable than linear RNA [18-20]. CircRNAs are an important part of non-coding RNA that are emerging as key new members of the gene regulatory milieu. The regulatory functions of circRNAs in physiological and pathological environments have been the focus of previous studies [21,22]. Recently, the role of circRNAs has been revealed in a variety of cancers, such as prostate cancer, glioma, breast cancer, colorectal cancer, and more [23-29]. A large number of studies have shown that circRNAs play a significant role in the progression of $\mathrm{BC}$, including cell proliferation, migration and invasion, metastasis, cell cycle, apoptosis and drug resistance [30-32]. Furthermore, it has also been demonstrated that the abnormal expression of circRNA is related to its pathological characteristics in bladder cancer tissue, which can be used as a potential biomarker for early screening, diagnosis and prognosis of bladder cancer. CircRNAs possess potential modes of specific action, serving as sponges for miRNAs and RNA-binding proteins, or acting as transcriptional regulators. The aim of this paper is to discuss the latest knowledge on the role of circRNAs in bladder carcinogenesis, including proliferation, invasion, metastasis, and therapeutic resistance, and to propose circRNAs that canserve as ideal biomarkers and/or therapeutic targets.

\section{Overview of circRNAs}

\subsection{Biogenesis and Classification of circRNAs}

Circular transcripts, first discovered in 1976 in a plant viroid, attracted little attention at the time and were treated as abnormal by-products or "splice noise" with low abundance and low functional potential [33-36]. Due to the development of high-throughput screening technology, more types of circRNAs have been identified in a variety of species and cell lines [22,37-40]. The expression level of circRNAs is relatively rich and highly conserved. The expression level of circRNAs is relatively common in eukaryotic cells and varies greatly due to the specificity of tissue and development stage [41-43].

In the light of composition and biogenesis mechanisms of RNA, circRNAs can be divided into four specific groups: exonic circRNAs (EcircRNAs), exon-intron circRNAs (EIciRNAs), circular intronic RNAs (CiRNAs), and intergenic circRNAs [41,44]. EcircRNAs containing exons are only produced in a course known as exon skip events or back-splicing circularization [45]. Lariat-driven circularization is a type of exon skipping process. PremRNA splicing is commonly known to be a two-step ester exchange reaction [46]. The adenosine hydroxyl group located at the $2^{\prime}$ branch point within the intron that is to be spliced attacks the intron upstream of the $5^{\prime}$ end in a nucleophilic manner. This produces a lariat intermediate closed covalently through the $2^{\prime}$ to $5^{\prime}$ phosphodiester bond. Then, the $3^{\prime}$ hydroxyl group of the upstream exon is free to attack the $5^{\prime}$ phosphate of the downstream exon, splicing out the intron completely and allowing the exons to be attached as a linear coding sequence [46]. After being processed through lariat model, pre-mRNAs form a lariat intermediate containing exons with the help of circular introns during internal splicing $[47,48]$. In the lariat intermediate, the $5^{\prime}$ terminal donor of an exon combines with the $3^{\prime}$ terminal acceptor of another exon and then forms an EcircRNA by eliminating introns between exons. Back-splicing circularization is another significant process to generate EcircRNAs. During the course of back-splicing circularization, the downstream $5^{\prime}$ terminal of an exon unites the upstream $3^{\prime}$ terminal of another exon $[49,50]$. In addition, a circular RNA can also be generated from a single exon, where the $5^{\prime}$ terminal of one exon is connected to the $3^{\prime}$ terminal of the same exon. Intron pairing-driven circularization is 
a widespread back-splicing mechanism, which is a process of circularization induced by reverse complementary sequences, thus generating EIciRNA or EcircRNA by removing introns [51,52]. Another back-splicing mechanism is RBP-driven circularization, beginning with back-splicing, and then relying on RBPs, flanking introns bind tightly to each other to form a circular RNA $[53,54]$. However, the formation of CiRNA depends on conserved sequences near the spliceosome [55]. Specifically, lariat introns can be produced by the combination of $3^{\prime}$ splice receptors and $5^{\prime}$ splice donors, and lariat introns can avoid degradation by debranching enzymes with the aid of conserved sequence constituted by $7 \mathrm{nt} \mathrm{GU}$-rich elements at $5^{\prime}$ splice site and $11 \mathrm{nt}$ C-rich elements at branch point site [56] (Figure 1).

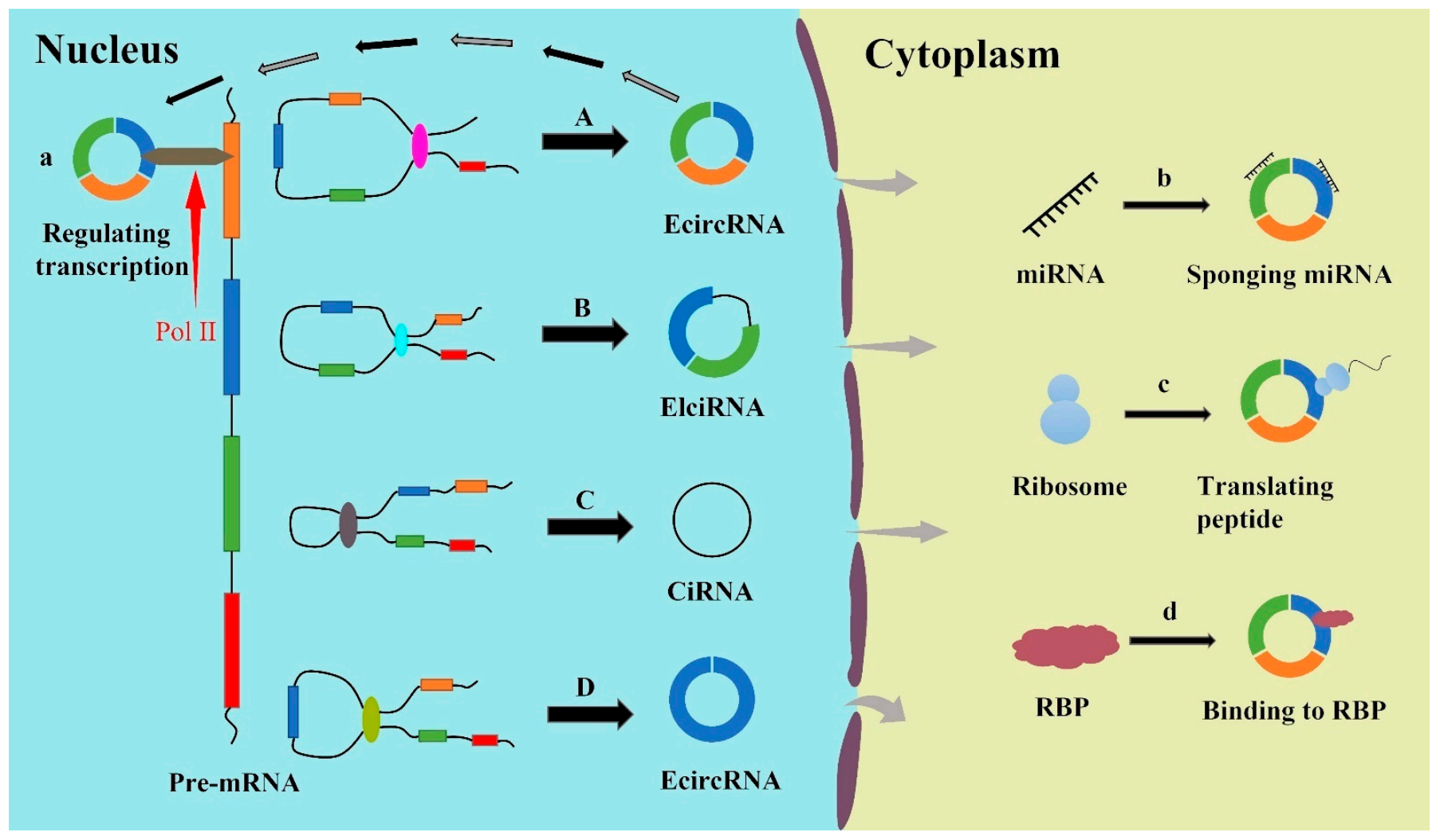

Figure 1. Biogenesis and function of circRNAs .A. EcircRNA is generated from linking the downstream $5^{\prime}$ terminal of an exon to the upstream $3^{\prime}$ terminal of another exon and cyclizing. B. EIciRNA is formed by intron pairing-driven circularization, which is induced by reverse complementary sequences. C. The formation of CiRNA depends on conserved sequences near the spliceosome. D. EcircRNA can also be generated from a single exon, where the $5^{\prime}$ terminal of one exon is connected to the $3^{\prime}$ terminal of the same exon. a. Regulation of gene transcription. b. MiRNA sponges. c. Translation into peptides and/or proteins. d. Interaction with functional proteins.

\subsection{CircRNA Identification and Database for circRNA Research}

High-throughput RNA-seq, RT-PCR/qPCR, Northern blot, circRNA microarray and other tools have been widely applied to identify and quantify circRNAs [57]. The presence and amount of circRNAs were revealed using high-throughput RNA-seq, which is equipped with next-generation sequencing in combination with ribosomal RNA depletion [58]. For known circRNAs, qRT-PCR using divergent primers and Northern blot using reverse splicing sequence- specific probes can be used to verify their presence and detect their quantities. CircRNAs can be specifically identified and quantified by circRNA microarray by binding sequence specific probes of circular junctions and external nuclease linear RNA consumption [59].

To analyze the information, regulatory networks and roles of circRNAs in diseases and other physiological processes, databases including Circbase, CIRC pedia V2 and Deepbase 2.0 containing vast quantities of circRNAs and relevant details about diverse species have 
been established [60-62]. The transcriptional regulation information of circRNAs can be supplied by the TRCirc database, and the sequencing results can be easily analyzed in the CirclncRNAnet database $[63,64]$.The network relationships between partial miRNAs and circRNAs as well as between proteins and circRNAs have already been elucidated by Starbase v2.0, CircInteractome and other databases, which provide a great assistance to study the functions of circRNAs [65-67]. CircRNADb and CSCD databases for analyzing protein-coding capabilities have also been founded $[68,69]$. Furthermore, certain clinically relevant patient information is available from Circ2Traits and CircRNA Disease databases, providing clues to delve into the potential of circRNAs as biomarkers in certain diseases [70,71]. With the application of more techniques to identify circRNAs and the continuous improvement of databases, the roles of circRNAs will be more fully elucidated.

\subsection{Functions of circRNAs}

CircRNAs exert their activities at various levels. (a) CircRNAs have been identified as critical regulators of the major signaling pathways involved in cancer progression [72]. Dysregulation of miRNA-mediated mRNA and correlative signaling pathways are closely interrelated to cancer progression and therapeutic resistance. Numerous studies have reported that circRNAs can function as miRNA sponges or competing endogenous RNA (ceRNAs) to repress miRNA activities [73-77]. As a result, the expression of target genes is upregulated. CircRNA ciRS-7 was the most typical one which possesses more than 70 conserved miRNA targets [78]. CiRS-7 can increase the expression of targets of miR7 via sponging miR-7. (b) The adjustment of circRNAs at transcriptional level may be controlled by intron sequence circRNA. Located in the nucleus, CiRNA and EIciRNAs may regulate the expression of their associated protein at the level of transcription and posttranscription [59]. Dominantly enriched in its parent genes transcriptional site, ci-ankrd52 was reported to have a positive effect on RNA pol II transcription and serve as a positive regulator for its parent gene transcription [55]. (c) CircRNAs were identified to combine with certain proteins to form particular circRNA-protein complexes (circRNPs), which can modulate the subcellular localization of proteins, the action of associated proteins and the transcription of parental genes. Ashwal-Fluss et al. reported that conservative binding sites bonded with MBL were positioned in circMBL and its flanking introns [79]. The level of circMBL biosynthesis depends on the degree of binding between MBL and its binding site. (d) Most circRNAs are derived from exons of pre-mRNA and were once thought to have no translational capability, but increasing evidence shows that circRNAs have great coding potential in a cap-independent way [80]. CircSHPRH was identified to encode a 146 amino acids protein which inhibits tumor growth by stopping ubiquitin proteasomemediated degradation of SHPRH protein in glioma [81]. In addition to regulating basic biological processes, circRNAs also play critical roles in the progression of different types of cancers [82-88], cardiovascular disorders [89-91], neuronal degenerative diseases [92-95], and other physiological conditions [96-101]. Due to the high stability of circRNAs, we believe that they can make monumental contributions to the diagnosis and treatment of diseases.

\section{Expression and Biological Functions of circRNAs in BC}

\subsection{Abnormal Expression of circRNAs in $B C$}

There is growing evidence that abnormal expression of circRNAs is associated with the development of BC. Several high-throughput experiments have shown that circRNA expression profiles are dysregulated in BC. Li et al. have characterized 316 differentially expressed circRNAs in high grade BC tissues, compared to adjacent non-cancerous ones; 205 circRNAs were found to be upregulated, while 111 were downregulated [102]. Shen et al. also analyzed the differential gene expression of normal bladder tissues and paired tumor tissues and identified 5578 upregulated and 5833 downregulated circRNAs. By RNA sequencing from four pairs of bladder cancer tissues, $\mathrm{Li}$ et al. found transcripts of 59 differentially expressed circRNAs. Compared with adjacent tissues, 7 were upregulated and 
52 were downregulated [102]. Li et al. analyzed abnormal circRNAs expression between $\mathrm{BC}$ and adjacent non neoplastic bladder tissues by circRNA microarray and identified 512 differentially expressed circRNAs (340 upregulated, 172 downregulated) [103]. On the basis of validation experiments, we have identified and analyzed a variety of specific circRNAs, suggesting that aberrant expression of circRNAs has potential therapeutic value.

\section{2. circRNAs Regulate Proliferation of $B C$}

\subsubsection{Oncogenic circRNAs in BC}

A study from Yang et al. indicated that circUVRAG was significantly upregulated in tissues and cell lines of $\mathrm{BC}$, and its knockdown dramatically inhibited cell proliferation via promoting miR-223, resulting in repression of FGFR2 [67] (Figure 2). CircRGNEF consists of 2 exons from the RGNEF gene and affected progression of $\mathrm{BC}$ cells via sponging miR-548, subsequently upregulating KIF2C levels [104]. Furthermore, dysregulation of the circRNA-mediated Tgf- $\beta 2 /$ smad3 signaling pathway also participated in progression of BC. For instance, Su et al. found that circRIP2 enhanced BC progression via the Tgf- $\beta 2$ /smad3 signaling pathway by sponging miR-1305 [105]. Similarly, Mao et al. demonstrated that hsa_circ_0068871 was upregulated in BC and promoted BC proliferation and apoptosis through FGFR3-induced activation of STAT3 pathway by sponging miR181a-5p [106]. Sponging miR-145-5p, the overexpressed circCEP128 was demonstrated to promote BC proliferation and inhibit apoptosis via modulating SOX11 [107]. CircDOCK1 was reported to be significantly increased in $\mathrm{BC}$ tissues, and its knockdown dramatically inhibited the progression of EJ-m3 and $5673 \mathrm{BC}$ lines through upregulating the expression of miR-132-3p [108]. Has_circ_0068307 markedly upregulated and promoted BC cells progression through miR-147/c-Myc pathway [109]. Additionally, circ_0008532 promoted BC growth through sponging miR-155-5p and miR-330-5p, subsequently increasing MTGR1 expression [110] (Table 1).

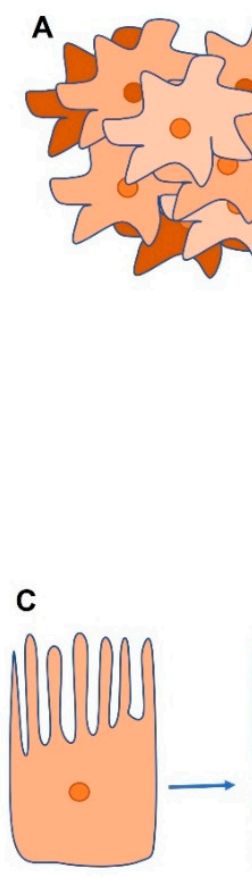

Epithelial cell

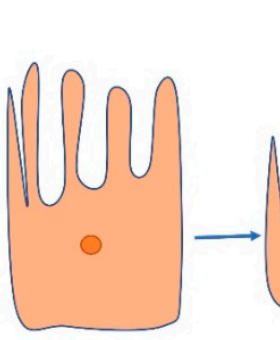

EM1

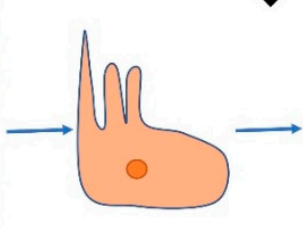

EM2

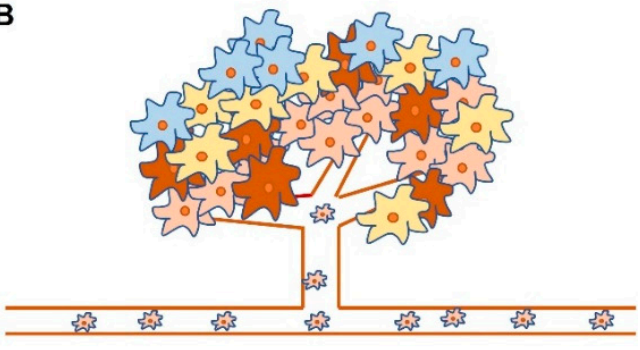

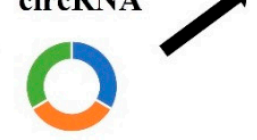

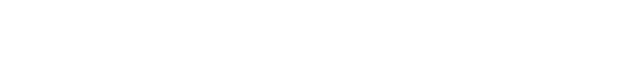

Figure 2. CircRNAs regulate cell proliferation, migration and invasion, and modulate epithelial-mesenchymal transition (EMT). (A). Roles of circRNAs in cell proliferation. (B). Roles of circRNAs in cell migration and invasion. (C). Roles of circRNAs in modulating EMT. 
Table 1. CircRNAs and their mechanisms in bladder cancer progression.

\begin{tabular}{|c|c|c|c|c|c|c|c|}
\hline CircRNA & Circbase ID & Gene Symbol & Expression & Function & $\begin{array}{c}\text { Molecular } \\
\text { Mechanism }\end{array}$ & $\begin{array}{c}\text { Target } \\
\text { Gene/Pathway }\end{array}$ & Reference \\
\hline CircUVRAG & Hsa_circ_0023642 & UVRAG & Upregulated & $\begin{array}{l}\text { Promoting cell proliferation } \\
\text { and migration }\end{array}$ & $\begin{array}{l}\text { Sponging for } \\
\text { miR-223 }\end{array}$ & FGFR2 & {$[67]$} \\
\hline CircRGNEF & Hsa_circ_0072995 & RGNEF & Upregulated & $\begin{array}{l}\text { Promoting cell proliferation } \\
\text { and invasion }\end{array}$ & $\begin{array}{l}\text { Sponging for } \\
\text { miR-548 }\end{array}$ & KIF2C & [104] \\
\hline CircRIP2 & Has_circ_0005777 & RIP2 & Upregulated & $\begin{array}{l}\text { Promoting cell proliferation } \\
\text { and metastasis }\end{array}$ & $\begin{array}{l}\text { Sponging for } \\
\text { miR-1305 }\end{array}$ & Tgf- $\beta 2 / \operatorname{smad} 3$ & [105] \\
\hline Circ_0068871 & Hsa_circ_0068871 & - & Upregulated & $\begin{array}{l}\text { Promoting cell proliferation } \\
\text { and migration }\end{array}$ & $\begin{array}{l}\text { Sponging for } \\
\text { miR-181a-5p }\end{array}$ & FGFR/STAT3 & [106] \\
\hline CircCEP128 & Hsa_circ_0102722 & - & Upregulated & $\begin{array}{l}\text { Promoting cell proliferation } \\
\text { and inhibiting cell apoptosis }\end{array}$ & $\begin{array}{l}\text { Sponging for } \\
\text { miR-145-5p }\end{array}$ & SOX11 & [107] \\
\hline CircDOCK1 & Hsa_circ_0020394 & - & Upregulated & $\begin{array}{l}\text { Promoting cell proliferation } \\
\text { and migration }\end{array}$ & $\begin{array}{l}\text { Sponging for } \\
\text { miR-132-3p }\end{array}$ & SOX5 & [108] \\
\hline Circ_0068307 & Hsa_circ_0068307 & - & Upregulated & $\begin{array}{c}\text { Promoting cell proliferation } \\
\text { and migration }\end{array}$ & $\begin{array}{l}\text { Sponging for } \\
\text { miR-147 }\end{array}$ & c-Myc & [109] \\
\hline Circ_0008532 & Hsa_circ_0008532 & - & Upregulated & $\begin{array}{l}\text { Promoting cell migration, } \\
\text { invasion, and angiogenesis }\end{array}$ & $\begin{array}{l}\text { Sponging for miR- } \\
155-5 \mathrm{p} / \mathrm{miR}-330-5 \mathrm{p}\end{array}$ & MTGR1 & [110] \\
\hline CircFOXO3 & Hsa_circ_0006404 & FOXO3 & Downregulated & $\begin{array}{l}\text { Inhibiting cell proliferation, } \\
\text { migration and invasion }\end{array}$ & $\begin{array}{l}\text { Sponging for } \\
\text { miR-9-5p }\end{array}$ & TGFBR2 & [111] \\
\hline CircFOXO3 & Hsa_circ_0006404 & FOXO3 & Downregulated & $\begin{array}{l}\text { Promoting promoted cell } \\
\text { apoptosis }\end{array}$ & $\begin{array}{l}\text { Sponging for } \\
\text { miR-191-5p }\end{array}$ & - & [112] \\
\hline CircBCRC-3 & Hsa_circ_0001110 & BCRC-3 & Downregulated & $\begin{array}{c}\text { Inhibiting cell proliferation, } \\
\text { and promoting cell cycle } \\
\text { arrest }\end{array}$ & $\begin{array}{l}\text { Sponging for } \\
\text { miR-182-5p }\end{array}$ & $\mathrm{P} 27$ & [113] \\
\hline CircCdr1as & Hsa_circ_0001946 & CDR & Downregulated & $\begin{array}{l}\text { Inhibiting cell proliferation, } \\
\text { migration and invasion }\end{array}$ & $\begin{array}{l}\text { Sponging for } \\
\text { miR-135a }\end{array}$ & $\mathrm{P} 21$ & [114] \\
\hline CircNR3C1 & Hsa_circ_0001543 & NR3C1 & Downregulated & $\begin{array}{l}\text { Inhibiting cell proliferation } \\
\text { and cell cycle progression }\end{array}$ & $\begin{array}{l}\text { Sponging for } \\
\text { miR-27a-3p }\end{array}$ & Cyclin D1 & [115] \\
\hline CircPTPRA & Hsa_circ_0006117 & PTPRA & Downregulated & Inhibiting cell proliferation & $\begin{array}{l}\text { Sponging for } \\
\text { miR-636 }\end{array}$ & KLF9 & [116] \\
\hline CircSLC8A1 & Hsa_circ_0000994 & SLC8A1 & Downregulated & $\begin{array}{l}\text { Inhibiting cell proliferation, } \\
\text { migration and invasion }\end{array}$ & $\begin{array}{l}\text { Sponging for } \\
\text { miR-130b/miR-494 }\end{array}$ & PTEN & [117] \\
\hline CircITCH & Hsa_circ_0001141 & ITCH & Downregulated & $\begin{array}{c}\text { Inhibiting cells proliferation, } \\
\text { migration, invasion and } \\
\text { metastasis }\end{array}$ & $\begin{array}{l}\text { Sponging for } \\
\mathrm{miR}-17 / \mathrm{miR}-224\end{array}$ & P21/PTEN & [118] \\
\hline CircBCRC4 & Hsa_circ_0001577 & RANBP9 & Downregulated & $\begin{array}{l}\text { Inhibiting cell viability and } \\
\text { promoting cell apoptosis }\end{array}$ & $\begin{array}{l}\text { Sponging for } \\
\text { miR-101 }\end{array}$ & $\mathrm{EZH} 2$ & [119] \\
\hline CircVANGL1 & Hsa_circ_0002623 & VANGL1 & Upregulated & $\begin{array}{c}\text { Promoting cell proliferation, } \\
\text { migration and invasion }\end{array}$ & $\begin{array}{l}\text { Sponging for } \\
\text { miR-1184 }\end{array}$ & IGFBP2 & [120] \\
\hline CircVANGL1 & Hsa_circ_0002623 & VANGL1 & Upregulated & $\begin{array}{c}\text { Promoting cell proliferation, } \\
\text { migration, and invasion }\end{array}$ & $\begin{array}{l}\text { Sponging for } \\
\text { miR-605-3p }\end{array}$ & VANGL1 & [121] \\
\hline CircCEP128 & Hsa_circ_0102722 & - & Upregulated & $\begin{array}{l}\text { Promoting cell proliferation } \\
\text { and migration, inhibiting } \\
\text { cell apoptosis and cell cycle } \\
\text { arrest }\end{array}$ & $\begin{array}{l}\text { Sponging for } \\
\text { miR-145-5p }\end{array}$ & MAPK/MYD88 & [122] \\
\hline Circ_0058063 & Hsa_circ_0058063 & - & Upregulated & $\begin{array}{l}\text { Promoting cell proliferation } \\
\text { and migration, inhibiting } \\
\text { cell apoptosis }\end{array}$ & $\begin{array}{l}\text { Sponging for } \\
\text { miR-145-5p }\end{array}$ & CDK6 & [123] \\
\hline Circ_0058063 & Hsa_circ_0058063 & - & Upregulated & $\begin{array}{l}\text { Promoting cell proliferation } \\
\text { and invasion, inhibiting } \\
\text { apoptosis }\end{array}$ & $\begin{array}{l}\text { Sponging for } \\
\text { miR-486-3p }\end{array}$ & FOXP4 & [124] \\
\hline CircTCF25 & Hsa_circ_0041103 & - & Upregulated & $\begin{array}{l}\text { Promoting cell proliferation } \\
\text { and migration }\end{array}$ & $\begin{array}{l}\text { Sponging for miR- } \\
107 / \mathrm{miR}-103-3 \mathrm{p}\end{array}$ & CDK6 & [125] \\
\hline CircTFRC & Has_circ_0001445 & TFRC & Upregulated & $\begin{array}{l}\text { Promoting cell proliferation } \\
\text { and invasion }\end{array}$ & $\begin{array}{l}\text { Sponging for } \\
\text { miR-107 }\end{array}$ & TFRC & [126] \\
\hline CircINTS4 & Hsa_circ_0002476 & INTS4 & Upregulated & $\begin{array}{c}\text { Promoting cell proliferation, } \\
\text { migration, cell cycle and } \\
\text { apoptosis }\end{array}$ & $\begin{array}{l}\text { Sponging for } \\
\text { miR-146b }\end{array}$ & $\begin{array}{l}\text { CARMA3/NFKB/ } \\
\text { P38 MAPK }\end{array}$ & [127] \\
\hline CircKIF4A & Hsa_circ_0007255 & - & Upregulated & $\begin{array}{l}\text { Promoting cell proliferation } \\
\text { and colony-formation ability }\end{array}$ & $\begin{array}{l}\text { Sponging for } \\
\text { miR-375 and } \\
\text { miR-1231 }\end{array}$ & NOTCH/PI3K/AKT & [128] \\
\hline Circ_0071662 & Hsa_circ_0071662 & TPPP1 & Downregulated & $\begin{array}{l}\text { Inhibiting cell proliferation } \\
\text { and invasion }\end{array}$ & $\begin{array}{l}\text { Sponging for } \\
\text { miR-146b-3p }\end{array}$ & HPGD/NF2 & [129] \\
\hline CircFAM114A2 & Hsa_circ_0001546 & FAM114A2 & Downregulated & $\begin{array}{l}\text { Inhibiting cell proliferation, } \\
\text { migration and invasion }\end{array}$ & $\begin{array}{l}\text { Sponging for } \\
\text { miR-762 }\end{array}$ & $\Delta \mathrm{NP63}$ & [130] \\
\hline
\end{tabular}


Table 1. Cont.

\begin{tabular}{|c|c|c|c|c|c|c|c|}
\hline CircRNA & Circbase ID & Gene Symbol & Expression & Function & $\begin{array}{c}\text { Molecular } \\
\text { Mechanism }\end{array}$ & $\begin{array}{c}\text { Target } \\
\text { Gene/Pathway }\end{array}$ & Reference \\
\hline Circ_0091017 & Hsa_circ_0091017 & - & Downregulated & $\begin{array}{l}\text { Inhibiting cell proliferation, } \\
\text { migration and invasion }\end{array}$ & $\begin{array}{l}\text { Sponging for } \\
\text { miR-589-5p }\end{array}$ & - & [131] \\
\hline Circ_0002024 & Hsa_circ_0002024 & - & Downregulated & $\begin{array}{l}\text { Inhibiting cell proliferation, } \\
\text { migration and invasion }\end{array}$ & $\begin{array}{l}\text { Sponging for } \\
\text { miR-197-3p }\end{array}$ & - & [132] \\
\hline CircUBXN7 & Hsa_circ_0001380 & UBXN7 & Downregulated & $\begin{array}{l}\text { Inhibiting cell proliferation, } \\
\text { migration and invasion }\end{array}$ & $\begin{array}{l}\text { Sponging for } \\
\text { miR-1247-3p }\end{array}$ & B4GALT3 & [133] \\
\hline CircFNDC3B & Hsa_circ_0006156 & FNDC3B & Downregulated & $\begin{array}{l}\text { Inhibiting cell proliferation, } \\
\text { migration and invasion }\end{array}$ & $\begin{array}{l}\text { Sponging for } \\
\text { miR-1178-3p }\end{array}$ & G3BP2/SRC/FAK & [134] \\
\hline Circ_0023642 & Hsa_circ_0023642 & UVRAG & Downregulated & Inhibiting cell invasion & $\begin{array}{l}\text { Sponging for } \\
\text { miR-490-5p }\end{array}$ & EGFR & [135] \\
\hline CircPTPRA & Hsa_circ_0006117 & PTPRA & Downregulated & $\begin{array}{l}\text { Inhibiting cell invasion, } \\
\text { metastasis and cell cycle }\end{array}$ & $\begin{array}{l}\text { Interacting with } \\
\text { IGF2BP1 }\end{array}$ & $\begin{array}{l}\text { M6A-modified } \\
\text { RNAs }\end{array}$ & [136] \\
\hline Circ_0006332 & Hsa_circ_0006332 & MYBL2 & Upregulated & $\begin{array}{c}\text { Promoting cell proliferation, } \\
\text { colony formation and } \\
\text { invasion }\end{array}$ & $\begin{array}{l}\text { Sponging for } \\
\text { miR-143 }\end{array}$ & MYBL2/EMT & [137] \\
\hline CircRIMS1 & Hsa_circ_0132246 & - & Upregulated & $\begin{array}{l}\text { Promoting cell proliferation, } \\
\text { migration and invasion }\end{array}$ & $\begin{array}{l}\text { Sponging for } \\
\text { miR-433-3p }\end{array}$ & CCAR1/EMT & [32] \\
\hline CircPRMT5 & Hsa_circ_0031250 & PRMT5 & Upregulated & $\begin{array}{c}\text { Promoting cell migration } \\
\text { and invasion }\end{array}$ & $\begin{array}{l}\text { Sponging for } \\
\text { miR-30c }\end{array}$ & EMT & [138] \\
\hline CircMYLK & Hsa_circ_0002768 & MYLK & Upregulated & $\begin{array}{l}\text { Promoting cell proliferation, } \\
\text { migration and angiogenesis }\end{array}$ & $\begin{array}{l}\text { Sponging for } \\
\text { miR-29a }\end{array}$ & $\begin{array}{l}\text { VEGFA/VEGFR2 } \\
\text { and Ras/ERK, } \\
\text { and EMT }\end{array}$ & [139] \\
\hline Circ_100984 & Hsa_circ_100984 & - & Upregulated & $\begin{array}{l}\text { Promoting cell proliferation, } \\
\text { migration and invasion }\end{array}$ & $\begin{array}{l}\text { Sponging for } \\
\text { miR-432-3p }\end{array}$ & $\begin{array}{l}\text { c-Jun } / \mathrm{YBX}-1 / \beta- \\
\text { catenin and } \\
\text { EMT }\end{array}$ & [140] \\
\hline CircRBPMS & Hsa_circ_0006539 & RBPMS & Downregulated & $\begin{array}{l}\text { Inhibiting cell proliferation } \\
\text { and metastasis }\end{array}$ & $\begin{array}{l}\text { Sponging for } \\
\text { miR-330-3p }\end{array}$ & RAI2/ERK/EMT & [141] \\
\hline CircST6GALNA & 6Hsa_circ_0088708 & ST6GALNAC6 & Downregulated & $\begin{array}{l}\text { Inhibiting cell proliferation, } \\
\text { migration, invasion }\end{array}$ & $\begin{array}{l}\text { Sponging for } \\
\text { miR-200a-3p }\end{array}$ & STMN1/EMT & [142] \\
\hline Circ_0000629 & Hsa_circ_0000629 & - & Downregulated & $\begin{array}{l}\text { Inhibiting cell migration, } \\
\text { invasion and growth }\end{array}$ & $\begin{array}{l}\text { Sponging for } \\
\text { miR-1290 }\end{array}$ & CDC73/EMT & [143] \\
\hline CircPICALM & Hsa_circ_0023919 & PICALM & Downregulated & & $\begin{array}{l}\text { Sponging for } \\
\text { miR-1265 }\end{array}$ & $\begin{array}{l}\text { STEAP4/pFAK- } \\
\text { Y397/EMT }\end{array}$ & [144] \\
\hline
\end{tabular}

\subsubsection{Anti-Oncogenic circRNAs in BC}

$\mathrm{Li}$ et al. found an antitumor circRNA, circ-FOXO3, which is produced from the members of the fork-head family and found that circ-FOXO3 plays antitumor roles in BC by regulating the miR-9-5p/TGFBR2 axis [111]. Wang et al. revealed that circ-FOXO3 accelerated the apoptosis of BC cells through direct interaction with miR-191-5p [112]. Sponging miR-182-5p, the circBCRC-3 was proved to suppress proliferation by promoting the miR-182-5p-oriented 3'UTR activity of p27 [113]. Li et al. indicated that circCdr1as was significantly downregulated in BC specimens, and its overexpression dramatically inhibited cell proliferation via promoting miR-135a [114]. CircNR3C1was composed of endto-end splicing of the exon-2 from the NR3C1 gene and inhibited proliferation of $\mathrm{BC}$ cells via sponging miR-27a-3p effectively, subsequently downregulating cyclin D1 levels [115]. CircPTPRA, which originated from the exon 8 and 9 of the PTPRA gene, was identified to sponge miR-636 to increase the expression of KLF9, suppressing proliferation of BC cells [116]. CircSLC8A1 regulated the PI3K-AKT pathway to repress BC progression via the miR-130b and miR-494/PTEN axis [117]. Yang et al. revealed that circ-ITCH inhibited the proliferative biological behaviors of BC via circ-ITCH/miR-17, $\mathrm{miR}-224 / \mathrm{p} 21$, PTEN axis [118]. Zeng et al. found that circRNA BCRC4 down-expressed in BC tissues and cell lines, and its forced expression inhibited viability and promoted apoptosis of UMUC3 and T24T cells through circBCRC4/microRNA-101/EZH2 signaling [119] (Table 1). 


\section{3. circRNAs Regulate Metastasis of BC}

\subsubsection{Oncogenic circRNAs in BC Migration or Invasion}

CircRNA VANGL1 may sponge various miRNAs, including miR-1184 and miR-605-3p. Yang et al. identified miR-1184 as a target of circVANGL1, while miR-1184 targeted IGFBP2, suggesting that circVANGL1 promoted bladder cancer invasion and migration through the circVANGL1/miR-1184/IGFBP2 network [120]. Another paper proved that overexpression of circVANGL1 promoted migration and invasion of BC cells by sponging miR-605-3p upregulating VANGL1 level [121]. Sun et al. stated that overexpression of circCEP128 may sponge miR-145-5p and upregulate MYD88 through MAPK signaling pathway to promote BC progression [122]. Additionally, Sun et al. identified circ_0058063, which also sponged miR-145-5p, was upregulated in BC and promoted migration but impaired cell apoptosis by regulating CDK6 expression [123]. Liang et al. suggested that circ_0058063 served as a sponge of miR-486-3p to block cell death and promote cell invasion by regulating FOXP4 expression [124]. CDK6 is also a target protein of miR-107, and circTCF25 can be used as a sponge for miR-107 and miR-103-3p to promote migration [125]. CircTFRC was also a sponge for miR-107, and the knockdown of circTFRC may decelerate invasion of BC cells by inhibiting TFRC [126]. Zhang et al. verified that circINTS4 promoted BC cell migration and cell cycle progression via promoting the NFKB signaling pathway and restraining P38 MAPK signaling pathway in a CARMA3-mediated manner [127]. Lu et al. demonstrated that circKIF4A was upregulated in BC cell lines, and its overexpression facilitated BC migration and metastatic ability through NOTCH2-induced activation of PI3K-AKT pathway by sponging miR-375 and miR-1231 [128] (Table 1).

\subsubsection{Anti-Oncogenic circRNAs in BC Migration or Invasion}

Circ_0071662, a circinate product of TPPP transcript, was confirmed to repress invasive biological behaviors by sponging miR-146b-3p, and then boosting HPGD and NF2 expression [129]. Hsa_circ_0001546 (circFAM114A2), which derived from the FAM114A2 gene and was spliced by exons $2-4$, was shown to possess potential biological roles in inhibiting migration and invasion of BC via a circFAM114A2/miR-762/ $\triangle$ NP63 axis [130]. Zhang et al. reported that hsa_circ_0091017 was remarkably downregulated in BC cell lines and tissues, and the inhibitory effect on the malignant phenotype may be reversed by overexpression of microRNA-589-5p [131]. By sponging miR-197-3p, circular RNA hsa_circ_0002024 was found to suppress migratory and invasive biological behaviors of BC cells [132]. Liu et al. elucidated that circUBXN7 act as a ceRNA of miR-1247-3p to enhance B4GALT3 expression, thus repressing cell invasion and viability [133]. Another study showed that circFNDC3B inhibited cancer cell migration and invasion by binding miR-1178-3p, which targeted the oncogene G3BP2, thereby suppressing the downstream SRC/FAK pathway [145]. EGFR pathway was connected to malignant biological behaviors. A study from Wu et al. revealed that circ_0023642 promoted invasion through acting as a miR-490-5p sponge via the EGFR pathway [135]. In addition, they also found that estrogen receptor alpha $(E R \alpha)$ altered circ_0023642 levels by regulating the expression of its host gene, UVRAG, uncovering upstream regulatory mechanism. Xie et al. described circPTPRA as a novel tumor suppressor which repressed cancer invasion and migration via endogenous inhibition of the recognition of IGF2BP1 from m6A-modified RNAs [136] (Table 1) (Figure 2).

\subsubsection{CircRNAs in Regulation of EMT}

Multiple researchers reported that circRNAs affected BC metastasis by modulating epithelial-mesenchymal transition (EMT) (Figure 2), which was involved in malignant biological functions of tumors [146]. One study showed that circ_0006332 sponged miR-143 to increase the expression of its target MYBL and consequently promoted EMT in bladder tumors [137]. CircRIMS1 was highly expressed in BC, and its knockdown significantly suppressed expression of $\mathrm{N}$-cadherin and vimentin, and enhanced expression of E-cadherin, suggesting suppression of EMT process [32]. Meanwhile, circPRMT5 was dramatically 
upregulated in BC and was positively correlated with pathological stage, and it significantly increased the aggressiveness ability of BC cells by specifically sponging miR-30c and promoting EMT [138]. Zhong et al. indicated that circ-MYLK promoted BC malignancy via facilitating VEGFA/VEGFR2 signaling and its downstream Ras/ERK pathway by sponging miR-29a, which dramatically boosted EMT in BC [139]. Tong et al. suggested that circ_100984/miR-432-3p axis modulated c-Jun/YBX-1/ $\beta$-catenin feedback loop to influence EMT and thus promote tumor progression [140]. CircRBPMS reduced the inhibition of RAI2 by sponging miR-330-3p, thereby suppressing the ERK signaling pathway and inhibiting the EMT process to repress BC progression [141]. Tan et al. proved that circST6GALNAC6 inhibited EMT and BC metastasis partly via the miR-200a-3p/STMN1axis [142]. Overexpression of circ_0000629 resulted in a significant increase in E-cadherin expression and a remarkable decrease in Vimentin, Snail, and N-cadherin expression, which inhibited the aggressiveness of BC [143]. CircPICALM served as a sponge for miR-1265 to modulate STEAP4 and further affected the condition of pFAK-Y397 and EMT, thus inhibiting BC progression [144]. EMT was one of the most significant molecular pathways that promoted metastatic ability of cancer cells and EMT was thought as a probable target of miRNAs in cancer cells $[147,148]$. Considering the functional relationship between circRNAs and miRNAs, the potential roles of circRNAs in regulating EMT is worthy of further exploration (Table 1).

\subsection{CircRNAs in BC Drug-Resistance and Chemo-Sensitization}

Surgical treatment of $\mathrm{BC}$ remains the preferred treatment option, but chemotherapy with gemcitabine and cisplatin is the standard first-line treatment for patients with advanced or metastatic BC [149]. However, chemotherapy resistance often leads to tumor recurrence and progression. Several studies have reported the relationship between circRNAs and chemotherapeutic resistance, suggesting that circRNAs may be potential therapeutic targets [150-154]. A study by Yuan et al. showed that upregulation of circular RNA Cdr1as is related to cisplatin sensitivity in BC patients by upregulating expression of APAF1 via miR-1270 repression [155]. CircHIPK3, which can bind to miR-558 directly, is significantly downregulated in gemcitabine resistant cells [156]. Su et al. identified that circELP3 promotes proliferation and reduces apoptosis by adapting to hypoxic tumor microenvironment and facilitates resistance of cisplatin by targeting cancer stem-like cells [157]. Meanwhile, the upregulation of circELP3 is related to higher lymphatic metastasis and pathological stage, which implies that circELP3 can be a potential therapeutic and prognostic target for BC patients. In another study, circFNTA was found to be extremely upregulated in cisplatin resistant BC cells [158]. CircFNTA can regulate cisplatin resistance by binding to miR-370-3p and altering KRAS activity. In addition, Chen et al. also found that androgen receptors (AR) affect circFNTA levels by inhibiting RNA editing gene ADAR2, thus increasing BC invasive ability and cisplatin resistance. Furthermore, the downregulation of circ102336 may increase cisplatin sensitivity in cisplatin-resistant BC cells by altering miR-515-5p [159]. circ_000285 levels in cisplatin sensitive patients was nearly 3 times higher than that in cisplatin resistant patients, and circRNA_000285 levels in parental cells was higher than that in cisplatin resistant RT4 cells, indicating that circRNA_000285 may serve as a biomarker for BC diagnosis and chemotherapy [160]. Additionally, Huang et al. figured out that circRNA_103809 can enhance chemo-resistance of BC cells by modulating miR-516a-5p/FBXL18 axis [161] (Table 2).

A growing number of circRNAs have been shown to be implicated in chemotherapy resistance in $\mathrm{BC}$. A meaningful method to achieve the reversal of drug resistance is to target these aberrantly expressed circRNAs. Drug resistance in BC can be reversed by exogenous expression of anti-oncogenic circRNAs or knockdown of oncogenic circRNAs by short hairpin RNAs (shRNAs) or small interfering RNAs (siRNAs). Drug-resistant advanced BC patients may benefit from circRNAs-based therapeutic interventions in combination with conventional chemotherapy or targeted therapy. 
Table 2. circRNAs and their values in bladder cancer chemo-sensitization and drug-resistance.

\begin{tabular}{|c|c|c|c|c|c|c|c|}
\hline CircRNA & CircBase ID & Gene Symbol & Expression & Clinical Value & Molecular Mechanism & Target Gene/Pathway & Reference \\
\hline CircCdr1as & Hsa_circ_0001946 & CDR1 & Downregulated & $\begin{array}{l}\text { Promoting cisplatin } \\
\text { sensitivity }\end{array}$ & Sponging for miR-1270 & APAF1 & [155] \\
\hline CircHIPK3 & Hsa_circ_0000284 & HIPK3 & Downregulated & $\begin{array}{l}\text { Promoting } \\
\text { gemcitabine } \\
\text { sensitivity }\end{array}$ & Sponging for miR-558 & HPSE, VEGF, MMP9 & [156] \\
\hline CircELP3 & Hsa_circ_0001785 & ELP3 & Upregulated & $\begin{array}{l}\text { Promoting cisplatin } \\
\text { resistance }\end{array}$ & Hypoxia-elevated & cancer stem-like cells & [157] \\
\hline CircFNTA & Hsa_circ_0084171 & FNTA & Upregulated & $\begin{array}{l}\text { Promoting cisplatin } \\
\text { resistance }\end{array}$ & $\begin{array}{l}\text { Sponging for } \\
\text { miR-370-3p }\end{array}$ & KRAS & [158] \\
\hline Circ_102336 & Hsa_circ_102336 & TAF4B & Upregulated & $\begin{array}{l}\text { Promoting cisplatin } \\
\text { resistance }\end{array}$ & $\begin{array}{l}\text { Sponging for } \\
\text { miR-515-5p }\end{array}$ & $\begin{array}{l}\text { ATP-binding cassette } \\
\text { (ABC) transporters } \\
\text { and apoptosis } \\
\text { pathways }\end{array}$ & [159] \\
\hline Circ_0000285 & Hsa_circ_0000285 & HIPK3 & Downregulated & $\begin{array}{l}\text { Promoting cisplatin } \\
\text { sensitivity }\end{array}$ & Unknown & Unknown & [160] \\
\hline Circ_103809 & Hsa_circ_0072088 & ZFR & Upregulated & $\begin{array}{c}\text { Promoting } \\
\text { chemo-resistance }\end{array}$ & $\begin{array}{l}\text { Sponging for } \\
\text { miR-516a-5p }\end{array}$ & FBXL18 & [161] \\
\hline
\end{tabular}

\section{CircRNAs Are Potential Diagnostic and Prognostic Biomarkers of Bladder Cancer}

Furthermore, circRNAs show interest as potential diagnostic and prognostic biomarkers for BC. Functional studies of circRNAs have shown that circRNAs have important clinical application value in regulating downstream target genes by acting as oncogenes or tumor suppressors. As mentioned above, circRNAs are characterized by their developmental stability, evolutionary conservation, specificity of tissue development, and abundance of tissue content, and they are widely found in blood, saliva, and urine. Therefore, circRNAs have become valuable biomarkers for the diagnosis, prognosis, and efficacy evaluation of bladder cancer.

Up until now, the relation between expression of circRNAs in tissues and clinical parameters have been widely reported. CircVANGL1, circ_0067934, circ-ASXL1, circGprc5a and circ_0001361 related to poor prognosis and clinical severity in patients with BC [121,162-165]. Meanwhile, circ_0000285, circMTO1, circLPAR1 were connected with good overall survival and good prognosis $[160,166,167]$. Dong et al. described the reduction of circACVR2A was related to advanced WHO grade and larger tumor size, implying circACVR2A may be a prognostic marker [168]. Moreover, upregulated circACVR2A inhibited invasion and migration through miR-626/EYA4 axis. Zhang and colleagues introduced circZFR as a cancer-independent prognostic biomarker for patients with BC [169]. Based on progression-free survival (PFS) and overall survival (OS) curves, downregulation of cirZFR significantly linked with better OS and PFS, which is opposed to circZFR upregulation in BC. Furthermore, circZFR downregulation is related to lower incidence of lymphatic metastasis. Thus, in combination with clinicopathological features, circZFR expression provides a better prognostic and diagnosis value in $\mathrm{BC}$ screening. A recent research using the FISH technique demonstrated the dramatic downregulation of circFUT8 in BC patients [170]. Moreover, clinicopathological results revealed that the upregulation of circFUT8 is negatively linked to the lymphatic metastasis in BC patients. Besides, the Kaplan-Meier analysis indicated circFUT8 may serve as a prognostic marker for good OS for BC patients. CircZKSCAN1 is another circRNA whose expression is evidently lower in patients at early-stage BC compared with advanced stage patients [171]. Additionally, survival analysis revealed BC patients with lower circZKSCAN1 expression suggested longer OS rates than patients with higher circZKSCAN1 expression. Besides, the upregulation of circZKSCAN1 along with the lymphatic metastasis are considered as independent prognostic factors of BC patients. As a result, circZKSCAN1 may be regarded as a biomarker for survival prediction. Yan et al. characterized circPICALM as a potential prognostic predictor for BC patients [144]. Their results showed that circPICALM is downregulated in patients at late-stage, and its reduction is linked to lower OS rates and higher TNM grades. These findings illustrate that circPICALM may be a potent prognostic indicator. 
Circ_0018069 is another new circRNA downregulated in BC tissues in comparison with the paired adjacent normal tissues [172]. Its deficiency in BC is notably associated with prognostic clinicopathological indices, for example, distant or lymphatic metastasis and poor OS. Based on these associations, circ_0018069 may be a valuable biomarker for prognosis and diagnosis prediction (Table 3).

The above examples idealize a blueprint for the application of circRNAs as biomarkers in the diagnosis and prognosis of BC. However, there are still issues that need to be addressed for the clinical application of circRNAs. Due to different expression in tissues, circRNAs are hard to detect in serum and plasma. In addition, the normal values and fluctuating ranges of circRNAs have not been determined, as well as whether their expressions are time-dependent. Despite these difficulties, circRNAs remain potential biomarker candidates that may offer additional diagnostic and prognostic possibilities for BC.

Table 3. CircRNAs and their values in bladder cancer diagnosis and prognosis.

\begin{tabular}{|c|c|c|c|c|c|c|c|}
\hline CircRNA & CircBase ID & Gene Symbol & Expression & Clinical Value & Molecular Mechanism & Target Gene/Pathway & Reference \\
\hline CircVANGL1 & Hsa_circ_0002623 & VANGL1 & Upregulated & Prognostic utility & $\begin{array}{l}\text { Sponging for } \\
\text { miR-605-3p }\end{array}$ & VANGL1 & [121] \\
\hline Circ_0067934 & Hsa_circ_0067934 & - & Upregulated & Prognostic utility & Sponging for miR-1304 & Myc & [162] \\
\hline CircASXL1 & Hsa_circ_0001136 & ASXL1 & Upregulated & $\begin{array}{l}\text { Prognostic and } \\
\text { diagnostic utility }\end{array}$ & Unknown & unknown & [163] \\
\hline CircGprc5a & Hsa_circ_02838 & - & Upregulated & Prognostic utility & Unknown & Gprc5a protein & [164] \\
\hline Circ_0001361 & Hsa_circ_0001361 & FNDC3B & Upregulated & Prognostic utility & $\begin{array}{l}\text { Sponging for } \\
\text { miR-491-5p }\end{array}$ & MMP9 & [165] \\
\hline Circ_0000285 & Hsa_circ_0000285 & HIPK3 & Downregulated & Prognostic utility & Unknown & unknown & [160] \\
\hline CircMTO1 & Hsa_circ_0007874 & MTO1 & Downregulated & Prognostic utility & Sponging for miR-221 & unknown & [166] \\
\hline CircLPAR1 & Hsa_circ_0087960 & LPAR1 & Downregulated & Prognostic utility & Sponging for miR-762 & unknown & [167] \\
\hline CircACVR2A & Hsa_circ_0001073 & ACVR2A & Downregulated & Prognostic utility & Sponging for miR-626 & EYA4 & [168] \\
\hline CircZFR & Hsa_circ_0072088 & ZFR & Upregulated & $\begin{array}{l}\text { Prognostic and } \\
\text { diagnostic utility }\end{array}$ & Sponging for miR-377 & ZEB2 & [169] \\
\hline CircFUT8 & Hsa_circ_0003028 & FUT8 & Downregulated & Prognostic utility & $\begin{array}{l}\text { Sponging for } \\
\text { miR-570-3p }\end{array}$ & KLF10 & [170] \\
\hline CircZKSCAN1 & Hsa_circ_0001727 & ZKSCAN1 & Downregulated & Prognostic utility & $\begin{array}{l}\text { Sponging for } \\
\text { miR-1178-3p }\end{array}$ & $\mathrm{P} 21$ & [171] \\
\hline CircPICALM & Hsa_circ_0023919 & PICALM & Downregulated & Prognostic utility & Sponging for miR-1265 & STEAP4 & [144] \\
\hline Circ_0018069 & Hsa_circ_0018069 & - & Downregulated & $\begin{array}{l}\text { Prognostic and } \\
\text { diagnostic utility }\end{array}$ & $\begin{array}{c}\text { Sponging for miR23c, } \\
\text { miR-34a-5p, } \\
\text { miR-181b-5p, } \\
\text { miR-454-3p and } \\
\text { miR-3666 }\end{array}$ & $\begin{array}{l}\text { ErbB, Ras, Foxo, and } \\
\text { the focal adhesion }\end{array}$ & [172] \\
\hline
\end{tabular}

\section{Relationships between circRNAs Quantities and Clinicopathologic Features in BC}

CircRNAs are closely associated with many clinicopathological features in BC, including tumor size, grade, tumor number, lymph node metastasis, distant metastasis, stage, and recurrence. CircRIP2 is evidently upregulated in BC tissues, and its expression quantities are closely connected with tumor number, tumor stage, and distant metastasis [105]. Wang et al. observed that hsa_circ_100146 is significantly upregulated in BC tissues and that hsa_circ_100146 levels are associated with tumor size, tumor grade, lymph node metastasis, and tumor number [173]. Similarly, circ_0006332 is dramatically upregulated in BC tissues, and its expression quantities are positively associated with tumor grade, tumor stage, and tumor size [137]. Li et al. demonstrated that circHIPK3 levels are evidently reduced in $\mathrm{BC}$ tissues and that this downregulation is correlated with tumor size, tumor stage, and lymph node metastasis [174]. CircFNDC3B has been reported to have low-expression in $\mathrm{BC}$ tissues, and its levels are associated with invasion, tumor grade and stage, and recurrence [145]. Similarly, circPICALM has a low expression in BC tissues, and its levels in BC tissues are related with tumor size, stage, grade and lymph node metastasis [144]. In contrast, hsa_circ_102336 is upregulated in BC cell lines and tissues, and its expression quantities are related with TNM stage, tumor size, grade, and distant metastasis [159]. 
Circ_0137439 has been identified to be upregulated in urine samples of patients with BC and the hsa_circ_0137439 levels are associated with tumor stage, grade, and lymph node metastasis [175]. Lu et al. revealed that low circSLC8A1 expression in BC tissues is correlated with tumor size, grade, and lymph node metastasis [117]. According to Liang and colleagues, hsa_circ_0058063 is significantly upregulated in BC tissues compared with normal tissues, and its expression quantities are associated with tumor number, grade, and lymph node metastasis [124]. The expression quantities of circ-ZKSCAN1 have been revealed to be decreased in BC tissues, and low levels of circ-ZKSCAN1 are positively related with tumor size, grade, recurrence, and lymph node metastasis [171]. Bi et al. implied that circ-BPTF is expressed at high levels in BC tissues, and its expression quantities are positively related with tumor size, recurrence, and lymph node metastasis [176]. In contrast, circ-ITCH is dramatically downregulated in BC tissues, and its quantities correlate negatively with tumor size, and stage [118]. Circ_0071196 has been revealed to be upregulated in BC tissues and cell lines, and high circ_0071196 expression quantities are positively related with tumor size, grade, and distant metastasis [177]. Similarly, circRGNEF is upregulated in BC tissues, and its quantities are correlated with tumor size, grade, and lymph node metastasis [104]. In addition, circZFR, circTFRC, hsa_circ_0068871, circ_0067934, circPTK2, circINTS4, circCEP128, circSEMA5A, circVANGL1, andcircEHBP1 $[31,106,107,121,126,127,162,169,178,179]$, which are overexpressed in BC tissues, and ciRs-6, hsa_circ_0077837, circCDYL, circFUT8, circPTPRA, circ_0071662, circFOXO3, circFAM114A2, circUBXN7, and circRBPMS [111,116,130,133,141,144,170,180-182], which are downregulated in $\mathrm{BC}$ tissues, are also reported to be associated with many clinicopathological features in BC (Table 4).

Table 4. Relationships between circRNAs quantities and clinicopathologic features in BC.

\begin{tabular}{|c|c|c|c|c|c|c|c|c|c|}
\hline CircRNA & CircBase ID & Gene Symbol & Expression & $\begin{array}{l}\text { Tumor } \\
\text { Stage }\end{array}$ & $\begin{array}{l}\text { Tumor } \\
\text { Grade }\end{array}$ & $\begin{array}{l}\text { Tumor } \\
\text { Size }\end{array}$ & $\begin{array}{c}\text { Tumor } \\
\text { Recurrence }\end{array}$ & $\begin{array}{l}\text { Tumor } \\
\text { Number }\end{array}$ & Reference \\
\hline CircRIP2 & Has_circ_0005777 & RIP2 & Upregulated & Yes & - & Yes & - & Yes & [105] \\
\hline Circ_100146 & Hsa_circ_100146 & - & Upregulated & Yes & Yes & Yes & - & Yes & [173] \\
\hline Circ_0006332 & Hsa_circ_0006332 & MYBL2 & Upregulated & Yes & Yes & Yes & - & - & [137] \\
\hline CircHIPK3 & Hsa_circ_0000284 & HIPK3 & Downregulated & Yes & - & Yes & - & - & [174] \\
\hline CircFNDC3B & Hsa_circ_0001361 & FNDC3B & Downregulated & Yes & Yes & - & Yes & - & [165] \\
\hline CircPICALM & Hsa_circ_0023919 & PICALM & Downregulated & Yes & Yes & Yes & - & Yes & [144] \\
\hline Circ_0137439 & Hsa_circ_0137439 & MDTH & Upregulated & Yes & Yes & - & - & - & [175] \\
\hline CircSLC8A1 & Hsa_circ_0000994 & SLC8A1 & Downregulated & Yes & Yes & Yes & - & - & [117] \\
\hline Circ_0058063 & Hsa_circ_0058063 & - & Upregulated & Yes & Yes & - & - & Yes & [124] \\
\hline CircZKSCAN1 & Hsa_circ_0001727 & ZKSCAN1 & Downregulated & Yes & Yes & - & - & Yes & {$[171]$} \\
\hline CircBPTF & Hsa_circ_0000799 & BPTF & Downregulated & Yes & - & Yes & Yes & - & [176] \\
\hline CircITCH & Hsa_circ_0001141 & ITCH & Downregulated & Yes & - & Yes & - & Yes & [118] \\
\hline Circ0071196 & Hsa_circ 0071196 & - & Upregulated & Yes & Yes & Yes & - & - & [177] \\
\hline CircRGNEF & Hsa_circ_0072995 & RGNEF & Upregulated & Yes & Yes & Yes & - & - & [104] \\
\hline CircZFR & Hsa_circ_0072088 & ZFR & Upregulated & Yes & Yes & Yes & Yes & - & [169] \\
\hline CircTFRC & Has_circ_0001445 & TFRC & Upregulated & Yes & Yes & Yes & - & - & [126] \\
\hline Circ_0068871 & Hsa_circ_0068871 & - & Upregulated & Yes & - & Yes & - & - & [106] \\
\hline Circ_0067934 & Hsa_circ_0067934 & - & Upregulated & Yes & - & Yes & - & - & [39] \\
\hline CircPTK2 & Hsa_circ_0003221 & PTK2 & Upregulated & Yes & Yes & Yes & - & - & [178] \\
\hline CircINTS4 & Hsa_circ_0002476 & INTS4 & Upregulated & Yes & Yes & Yes & - & - & [127] \\
\hline CircCEP128 & Hsa_circ_0102722 & - & Upregulated & Yes & - & Yes & - & - & [107] \\
\hline CircSEMA5A & Hsa_circ_0071820 & SEMA5A & Upregulated & Yes & Yes & Yes & - & Yes & [179] \\
\hline CircVANGL1 & Hsa_circ 0002623 & VANGL1 & Upregulated & Yes & Yes & Yes & - & - & [121] \\
\hline CircEHBP1 & Hsa_circ_0005552 & - & Upregulated & Yes & Yes & Yes & - & - & [31] \\
\hline CiRs_6 & Hsa_circ_0006260 & SLC41A2 & Downregulated & Yes & Yes & Yes & - & Yes & [180] \\
\hline Circ_0077837 & Hsa_circ_0077837 & - & Downregulated & Yes & Yes & Yes & - & Yes & [181] \\
\hline CircCDYL & Hsa_circ_0008285 & - & Downregulated & Yes & Yes & Yes & - & - & [182] \\
\hline CircFUT8 & Hsa_circ_0003028 & FUT8 & Downregulated & Yes & Yes & Yes & - & Yes & {$[170]$} \\
\hline CircPTPRA & Hsa_circ_0006117 & PTPRA & Downregulated & Yes & Yes & Yes & - & Yes & [116] \\
\hline Circ_0071662 & Hsa_circ_0071662 & ТРPP1 & Circ_0071662 & Yes & Yes & Yes & - & - & [129] \\
\hline CircFOXO3 & Hsa_circ_0006404 & FOXO3 & Downregulated & Yes & Yes & Yes & - & - & [111] \\
\hline CircFAM114A2 & Hsa_circ_0001546 & FAM114A2 & Downregulated & Yes & Yes & Yes & - & - & [130] \\
\hline CircUBXN7 & Hsa_circ_0001380 & UBXN7 & Downregulated & Yes & Yes & Yes & - & - & [133] \\
\hline CircRBPMS & Hsa_circ_0006539 & RBPMS & Downregulated & Yes & Yes & Yes & - & - & [87] \\
\hline
\end{tabular}

\section{Limitations and Prospects}

Currently, there is growing interest in circRNAs and in gaining a better understanding of their roles in BC. However, the clinical use of circRNAs in BC remains largely unexplored and further studies are required before they can be integrated into clinical practice. Unlike 
prostate cancer, bladder cancer has no specific serum tumor markers like prostate specific antigen (PSA). Its diagnosis relies largely on clinical manifestations and imaging examination. This requires us to pay attention to find highly effective and sensitive biomarkers. In addition, the continuous development of modern medicine has enabled the transformation of oncology therapy from traditional treatment to a targeted treatment. Targeted treatment can specifically kill tumor cells without damaging normal peritumoral cells. However, resistance to targeted drugs is emerging in tumor cells. The mechanism of drug resistance relates to circRNAs, which provides a direction for further research.

In recent years, numerous studies have reported that after certain circRNAs were overexpressed or downregulated, the function of tumor cell lines were affected to varying degrees. Certain processes were reversed or enhanced partially, emphasizing the potential ability of circRNAs in the adjustment of tumor diseases, which is of great importance for clinical application.

There are still many obstacles to overcome in the clinical application of circular RNAs. First of all, we can identify a large number of differentially expressed circRNAs in cancer tissues and adjacent tissues using high-throughput sequencing, which is a credible approach that depends on the quality of RNA samples [183], but their functions and mechanisms have not been studied. Most usable RNA sequencing databases are pretreated via a poly (A) depuration step which can eliminate circRNAs, resulting in incomplete discovery of circRNAs. Furthermore, this technique is usually confined to a small sample size and limited tissue types, which is difficult for experienced pathologists to conduct an evaluation of [184]. Moreover, qRT-PCR has been used in most studies instead of Northern blotting to identify and verify circRNAs differentially expressed in RNA-seq due to its relative convenience and efficiency. However, certain circRNAs cannot be distinguished due to the occupation of different qRT-PCR primers on the back-splicing junction [185]. In qRT-PCR, circRNAs can only be differentiated from exon iteration by RNase or poly (A) enrichment pretreatment [186]. It has confirmed that several parental genes can encode or splice circRNAs, but the underlying associations and functional relationships between them are usually not as relevant as expected. According to the standardization of biomarkers, only a small part of the differentially expressed circRNAs meet the conditions, and only a small number of them have completed experiments in vivo and in vitro to prove their roles in tumor diagnosis, treatment and prognosis. In addition, there is no standard naming rules for circRNAs, which may lead to repeated studies on the same circRNA. Fortunately, many bioinformatics algorithms have been developed and progressively applied to study circRNAs. Certain algorithms call for gene annotation tables, while others need to be studied from scratch, which can lessen the existence of false positives and prevent the omission of unannotated specific circRNAs due to a lack of uniform naming [187]. Through the prediction from bioinformatics algorithms, the hypothetical interaction between circRNAs and miRNAs can be checked by stoichiometric relationship, but this method is difficult to conduct because a great number of cells that differentially express circRNAs and miRNAs need to be analyzed simultaneously. Meanwhile, luciferase reporter analysis, as a representative of classical methods to determine direct binding, is seldom used in the studies of circRNAs. The location and metabolism of circRNAs have also been rarely reported. A large number of hypotheses have been proposed, including the secretion of circRNAs into exosomes, which need more studies to verify. Many investigations have concentrated on the function of circRNAs as miRNA sponges while ignoring other underlying features of circRNAs. Recent research has challenged the conventional wisdom, for instance, the absence of MREs do not affect the inhibitory actions of circRNAs on specific target miRNAs and there are raising questions about the structural foundation of the miRNA "sponge" [188]. No translatable circRNAs were identified in osteosarcoma by ribosome footprint detection, which questions the reliability of the protein coding capacity [189]. Since circRNA research is still in its infancy, these multifarious problems provided by these challenges deserve deeper explorations. With innovations of 
molecular biological techniques, people believe that those challenges will eventually be overcome, possibly leading to breakthroughs in circRNA research.

The epigenetic changes in human malignancies are primarily histone modifications, gene promoter hypermethylation, global genomic hypomethylation and modified miRNA expression patterns [190]. Thus, the differential expressions of circRNAs in BC associated with epigenetic changes in the genome will be an interesting direction to investigate. Furthermore, it has been shown that in colorectal cancer, the expression of circRNAs is modulated by mutant cis-acting elements. Whether the same modalities of regulation exist in $\mathrm{BC}$ and their roles in circRNAs biogenesis deserve further exploration. The posttranscriptional chemical modification of RNAs may be essential for their functionality and stability. Therefore, the exploration of chemical modification of circRNAs to achieve the adjustment of their functions is also a possible research direction. With the establishment of databases such as CircBase, CircNet and DeepBasev2.0, we can improve the naming system to unify the IDs of circRNAs $[60,62,191]$. Databases need to be updated in an immediate manner to effectively evade errors caused by bioinformatics algorithm and improve the validity of research hypotheses. In addition, there are more circRNAs detection methods developed. On top of qRT-PCR and Northern blotting, in situ hybridization (ISH) and fluorescence in situ hybridization (FISH) address the expression and distribution of circRNAs by providing direct visualization of spatial information [37]. The separation and sequencing of single cell are more suitable for detecting differentially expressed circRNAs in a cohort of cells or tissues. In terms of probing the associations between circRNAs and parental genes, clustered regularly interspaced short palindromic repeats/Cas9 (CRISPRcas9) is more advantageous [192]. As research techniques and horizons continue to be updated and expanded, our understanding of circRNAs in BC will be further enhanced.

\section{Conclusions}

With the significant progress of RNA research, circRNAs have attracted extensive attention of researchers and have gradually become an emerging frontier in cancer research. A soaring number of circRNA transcripts have been discovered, and certain circRNAs have been proven to be functional ncRNAs associated with malignant phenotypes and clinical manifestations. In this review, we not only introduced the biogenesis and function of circRNAs, but also the role of circRNAs as clinical biomarkers in the diagnosis, prognosis, and drug resistance of $\mathrm{BC}$, and further discuss the functions and significance of circRNAs in $\mathrm{BC}$. Notably, current research primarily reveals the role of circRNAs as miRNA sponges, while other potential functions of circRNAs in BC need to be further studied. Although research in circRNA regulation of bladder cancer is still in its infancy and many questions remain unanswered, we believe that circRNAs can provide a new avenue for tumor treatment.

Author Contributions: K.S. and D.W. were involved in the design of the review, collection of the related papers, and the writing of all tables, figures and manuscript. B.B.Y. and J.M. revised the manuscript. All authors have read and agreed to the published version of the manuscript.

Funding: This work was supported by the National Natural Science Foundation of China (no. 82073131, 81572835, 81870525) and Yantai Science and Technology Plan Project (no.2021MSGY047).

Institutional Review Board Statement: Not applicable.

Informed Consent Statement: Not applicable.

Conflicts of Interest: No conflicts of interest were declared.

\section{References}

1. Antoni, S.; Ferlay, J.; Soerjomataram, I.; Znaor, A.; Jemal, A.; Bray, F. Bladder Cancer Incidence and Mortality: A Global Overview and Recent Trends. Eur. Urol. 2017, 71, 96-108. [CrossRef] [PubMed]

2. Ploeg, M.; Aben, K.K.H.; Kiemeney, L.A. The present and future burden of urinary bladder cancer in the world. World J. Urol. 2009, 27, 289-293. [CrossRef]

3. Mattiuzzi, C.; Lippi, G. Cancer statistics: A comparison between World Health Organization (WHO) and Global Burden of Disease (GBD). Eur. J. Public Health 2019, 30, 1026-1027. [CrossRef] [PubMed] 
4. Witjes, J.A.; Bruins, H.M.; Cathomas, R.; Compérat, E.M.; Cowan, N.C.; Gakis, G.; Hernández, V.; Espinós, E.L.; Lorch, A.; Neuzillet, Y.; et al. European association of urology guidelines on muscle-invasive and metastatic bladder cancer: Summary of the 2020 guidelines. Eur. Urol. 2021, 79, 82-104. [CrossRef]

5. $\quad$ Spiess, P.E.; Agarwal, N.; Bangs, R.; Boorjian, S.A.; Buyyounouski, M.K.; Clark, P.E.; Downs, T.M.; Efstathiou, J.A.; Flaig, T.W.; Friedlander, T.; et al. Bladder Cancer, Version 5.2017, NCCN Clinical Practice Guidelines in Oncology. J. Natl. Compr. Cancer Netw. 2017, 15, 1240-1267. [CrossRef] [PubMed]

6. $\quad$ Fischer-Valuck, B.W.; Michalski, J.M.; Contreras, J.A.; Brenneman, R.; Christodouleas, J.P.; Abraham, C.D.; Kim, E.H.; Arora, V.K.; Bullock, A.D.; Carmona, R.; et al. A propensity analysis comparing definitive chemo-radiotherapy for muscle-invasive squamous cell carcinoma of the bladder vs. Urothelial carcinoma of the bladder using the national cancer database. Clin. Transl. Radiat. Oncol. 2019, 15, 38-41. [CrossRef]

7. Dreicer, R. Chemotherapy for advanced urothelial cancer: End of the beginning? Lancet Oncol. 2017, 18, 567-569. [CrossRef]

8. Torgovnick, A.; Schumacher, B. DNA repair mechanisms in cancer development and therapy. Front. Genet. 2015, 6, 157. [CrossRef]

9. Chamie, K.; Litwin, M.S.; Bassett, J.C.; Daskivich, T.J.; Lai, J.; Hanley, J.M.; Konety, B.R.; Saigal, C.S. Urologic Diseases in America, P. Re-currence of high-risk bladder cancer: A population-based analysis. Cancer 2013, 119, 3219-3227. [CrossRef]

10. Abdollah, F.; Gandaglia, G.; Thuret, R.; Schmitges, J.; Tian, Z.; Jeldres, C.; Passoni, N.M.; Briganti, A.; Shariat, S.F.; Perrotte, P.; et al. Incidence, survival and mortality rates of stage-specific bladder cancer in United States: A trend analysis. Cancer Epidemiol. 2013, 37, 219-225. [CrossRef] [PubMed]

11. Nakai, Y.; Nonomura, N.; Kawashima, A.; Mukai, M.; Nagahara, A.; Nakayama, M.; Takayama, H.; Nishimura, K.; Okuyama, A. Tumor Multiplicity is an Independent Prognostic Factor of Non-muscle-invasive High-grade (T1G3) Bladder Cancer. Jpn. J. Clin. Oncol. 2009, 40, 252-257. [CrossRef]

12. Xie, Q.; Chen, C.; Li, H.; Xu, J.; Wu, L.; Yu, Y.; Ren, S.; Li, H.; Hua, X.; Yan, H.; et al. miR-3687 Overexpression Promotes Bladder Cancer Cell Growth by Inhibiting the Negative Effect of FOXP1 on Cyclin E2 Transcription. Mol. Ther. 2019, 27, 1028-1038. [CrossRef]

13. Chen, Z.; Chen, X.; Xie, R.; Huang, M.; Dong, W.; Han, J.; Zhang, J.; Zhou, Q.; Li, H.; Huang, J.; et al. DANCR Promotes Metastasis and Proliferation in Bladder Cancer Cells by Enhancing IL-11-STAT3 Signaling and CCND1 Expression. Mol. Ther. 2019, 27, 326-341. [CrossRef]

14. Xu, J.; Yang, R.; Hua, X.; Huang, M.; Tian, Z.; Li, J.; Lam, H.Y.; Jiang, G.; Cohen, M.; Huang, C. IncRNA SNHG1 Promotes Basal Bladder Cancer Invasion via Interaction with PP2A Catalytic Subunit and Induction of Autophagy. Mol. Ther. Nucleic Acids 2020, 21, 354-366. [CrossRef] [PubMed]

15. Li, Y.; Li, G.; Guo, X.; Yao, H.; Wang, G.; Li, C. Non-coding RNA in bladder cancer. Cancer Lett. 2020, 485, 38-44. [CrossRef] [PubMed]

16. Nunes, S.P.; Henrique, R.; Jerónimo, C.; Paramio, J.M. DNA Methylation as a Therapeutic Target for Bladder Cancer. Cells 2020, 9, 1850. [CrossRef] [PubMed]

17. Hoffman, A.M.; Cairns, P. Epigenetics of kidney cancer and bladder cancer. Epigenomics 2011, 3, 19-34. [CrossRef]

18. Suzuki, H.; Zuo, Y.; Wang, J.; Zhang, M.Q.; Malhotra, A.; Mayeda, A. Characterization of rnase r-digested cellular rna source that consists of lariat and circular rnas from pre-mrna splicing. Nucleic Acids Res. 2006, 34, e63. [CrossRef]

19. Chen, L.-L.; Yang, L. Regulation of circRNA biogenesis. RNA Biol. 2015, 12, 381-388. [CrossRef]

20. Chen, I.; Chen, C.Y.; Chuang, T.J. Biogenesis, identification, and function of exonic circular rnas. Wiley Inter. Discip Rev. RNA 2015, 6, 563-579. [CrossRef]

21. Patop, I.L.; Wust, S.; Kadener, S. Past, present, and future of circrnas. EMBO J. 2019, 38, e100836. [CrossRef]

22. Memczak, S.; Jens, M.; Elefsinioti, A.; Torti, F.; Krueger, J.; Rybak-Wolf, A.; Maier, L.; Mackowiak, S.; Gregersen, L.H.; Munschauer, M.; et al. Circular RNAs are a large class of animal RNAs with regulatory potency. Nature 2013, 495, 333-338. [CrossRef]

23. Tucker, D.; Zheng, W.; Zhang, D.-H.; Dong, X. Circular RNA and its potential as prostate cancer biomarkers. World J. Clin. Oncol. 2020, 11, 563-572. [CrossRef] [PubMed]

24. Artemaki, P.I.; Scorilas, A.; Kontos, C.K. Circular RNAs: A New Piece in the Colorectal Cancer Puzzle. Cancers 2020, $12,2464$. [CrossRef] [PubMed]

25. Li, J.; Yang, J.; Zhou, P.; Le, Y.; Zhou, C.; Wang, S.; Xu, D.; Lin, H.-K.; Gong, Z. Circular RNAs in cancer: Novel insights into origins, properties, functions and implications. Am. J. Cancer Res. 2015, 5, 472-480.

26. He, X.; Xu, T.; Hu, W.; Tan, Y.; Wang, D.; Wang, Y.; Zhao, C.; Yi, Y.; Xiong, M.; Lv, W.; et al. Circular RNAs: Their Role in the Pathogenesis and Orchestration of Breast Cancer. Front. Cell Dev. Biol. 2021, 9. [CrossRef]

27. Shahzad, U.; Krumholtz, S.; Rutka, J.; Das, S. Noncoding RNAs in Glioblastoma: Emerging Biological Concepts and Potential Therapeutic Implications. Cancers 2021, 13, 1555. [CrossRef]

28. Fang, L.; Du, W.W.; Lyu, J.; Dong, J.; Zhang, C.; Yang, W.; He, A.; Kwok, Y.S.S.; Ma, J.; Wu, N.; et al. Enhanced breast cancer progression by mutant p53 is inhibited by the circular RNA circ-Ccnb1. Cell Death Differ. 2018, 25, 2195-2208. [CrossRef] [PubMed]

29. Zhou, C.; Liu, H.-S.; Wang, F.-W.; Hu, T.; Liang, Z.-X.; Lan, N.; He, X.-W.; Zheng, X.-B.; Wu, X.-J.; Xie, D.; et al. circCAMSAP1 Promotes Tumor Growth in Colorectal Cancer via the miR-328-5p/E2F1 Axis. Mol. Ther. 2019, 28, 914-928. [CrossRef]

30. Xie, F.; Xiao, X.; Tao, D.; Huang, C.; Wang, L.; Liu, F.; Zhang, H.; Niu, H.; Jiang, G. circNR3C1 Suppresses Bladder Cancer Progression through Acting as an Endogenous Blocker of BRD4/C-myc Complex. Mol. Ther. Nucleic Acids 2020, 22, 510-519. [CrossRef] 
31. Zhu, J.; Luo, Y.; Zhao, Y.; Kong, Y.; Zheng, H.; Li, Y.; Gao, B.; Ai, L.; Huang, H.; Huang, J.; et al. Circehbp1 promotes lymphangiogenesis and lymphatic metastasis of bladder cancer via mir-130a-3p/tgfbetar1/vegf-d signaling. Mol. Ther. J. Am. Soc. Gene Therapy. 2021, 29, 1838-1852. [CrossRef]

32. Wang, F.; Fan, M.; Cai, Y.; Zhou, X.; Tai, S.; Yu, Y.; Wu, H.; Zhang, Y.; Liu, J.; Huang, S.; et al. Circular RNA circRIMS1 Acts as a Sponge of miR-433-3p to Promote Bladder Cancer Progression by Regulating CCAR1 Expression. Mol. Ther. Nucleic Acids 2020, 22, 815-831. [CrossRef] [PubMed]

33. Sanger, H.L.; Klotz, G.; Riesner, D.; Gross, H.J.; Kleinschmidt, A.K. Viroids are single-stranded covalently closed circular RNA molecules existing as highly base-paired rod-like structures. Proc. Natl. Acad. Sci. USA 1976, 73, 3852-3856. [CrossRef] [PubMed]

34. Kos, A.; Dijkema, R.; Arnberg, A.C.; Van Der Meide, P.H.; Schellekens, H. The hepatitis delta ( $\delta$ ) virus possesses a circular RNA. Nature 1986, 323, 558-560. [CrossRef]

35. Pasman, Z.; Been, M.D.; Garcia-Blanco, M.A. Exon circularization in mammalian nuclear extracts. RNA 1996, 2, 603-610. [PubMed]

36. Capel, B.; Swain, A.; Nicolis, S.; Hacker, A.; Walter, M.; Koopman, P.; Goodfellow, P.; Lovell-Badge, R. Circular transcripts of the testis-determining gene Sry in adult mouse testis. Cell 1993, 73, 1019-1030. [CrossRef]

37. Barrett, S.P.; Salzman, J. Circular RNAs: Analysis, expression and potential functions. Development 2016, 143, 1838-1847. [CrossRef] [PubMed]

38. Rybak-Wolf, A.; Stottmeister, C.; Glažar, P.; Jens, M.; Pino, N.; Giusti, S.; Hanan, M.; Behm, M.; Bartok, O.; Ashwal-Fluss, R.; et al. Circular RNAs in the Mammalian Brain Are Highly Abundant, Conserved, and Dynamically Expressed. Mol. Cell 2015, 58, 870-885. [CrossRef]

39. Du, W.W.; Yang, W.; Li, X.; Fang, L.; Wu, N.; Li, F.; Chen, Y.; He, Q.; Liu, E.; Yang, Z.; et al. The circular rna circska3 binds integrin beta1 to induce invadopodium formation enhancing breast cancer invasion. Mol. Ther. 2020, 28, 1287-1298. [CrossRef]

40. Du, W.W.; Xu, J.; Yang, W.; Wu, N.; Li, F.; Zhou, L.; Wang, S.; Li, X.; He, A.T.; Du, K.Y.; et al. A Neuroligin Isoform Translated by circNlgn Contributes to Cardiac Remodeling. Circ. Res. 2021, 129, 568-582. [CrossRef]

41. Salzman, J.; Chen, R.E.; Olsen, M.N.; Wang, P.L.; Brown, P.O. Cell-type specific features of circular rna expression. PLoS Genet. 2013, 9, e1003777. [CrossRef]

42. Du, W.W.; Zhang, C.; Yang, W.; Yong, T.; Awan, F.M.; Yang, B.B. Identifying and characterizing circrna-protein interaction. Theranostics 2017, 7, 4183-4191. [CrossRef] [PubMed]

43. Du, W.W.; Yang, W.; Chen, Y.; Wu, Z.-K.; Foster, F.S.; Yang, Z.; Li, X.; Yang, B.B. Foxo3 circular RNA promotes cardiac senescence by modulating multiple factors associated with stress and senescence responses. Eur. Hear. J. 2016, 38, 1402-1412. [CrossRef]

44. Zhao, X.; Cai, Y.; Xu, J. Circular rnas: Biogenesis, mechanism, and function in human cancers. Int. J. Mol. Sci. 2019, 20, 3926. [CrossRef] [PubMed]

45. Wang, Y.; Wang, Z. Efficient backsplicing produces translatable circular mRNAs. RNA 2014, 21, 172-179. [CrossRef]

46. Eger, N.; Schoppe, L.; Schuster, S.; Laufs, U.; Boeckel, J.-N. Circular RNA Splicing. Circ. RNAs 2018, 1087, 41-52. [CrossRef]

47. Barrett, S.P.; Wang, P.L.; Salzman, J. Circular RNA biogenesis can proceed through an exon-containing lariat precursor. eLife 2015, 4, e07540. [CrossRef] [PubMed]

48. Starke, S.; Jost, I.; Rossbach, O.; Schneider, T.; Schreiner, S.; Hung, L.-H.; Bindereif, A. Exon Circularization Requires Canonical Splice Signals. Cell Rep. 2015, 10, 103-111. [CrossRef]

49. Kristensen, L.S.; Andersen, M.S.; Stagsted, L.V.W.; Ebbesen, K.K.; Hansen, T.B.; Kjems, J. The biogenesis, biology and characterization of circular RNAs. Nat. Rev. Genet. 2019, 20, 675-691. [CrossRef]

50. Liang, D.; Wilusz, J.E. Short intronic repeat sequences facilitate circular rna production. Genes Dev. 2014, 28, 2233-2247. [CrossRef]

51. Zhang, X.-O.; Wang, H.-B.; Zhang, Y.; Lu, X.; Chen, L.-L.; Yang, L. Complementary Sequence-Mediated Exon Circularization. Cell 2014, 159, 134-147. [CrossRef]

52. Li, Z.; Huang, C.; Bao, C.; Chen, L.; Lin, M.; Wang, X.; Zhong, G.; Yu, B.; Hu, W.; Dai, L.; et al. Exon-intron circular RNAs regulate transcription in the nucleus. Nat. Struct. Mol. Biol. 2015, 22, 256-264. [CrossRef] [PubMed]

53. Conn, S.; Pillman, K.; Toubia, J.; Conn, V.M.; Salmanidis, M.; Phillips, C.; Roslan, S.; Schreiber, A.; Gregory, P.; Goodall, G.J. The RNA Binding Protein Quaking Regulates Formation of circRNAs. Cell 2015, 160, 1125-1134. [CrossRef]

54. Huang, C.; Liang, D.; Tatomer, D.C.; Wilusz, J.E. A length-dependent evolutionarily conserved pathway controls nuclear export of circular RNAs. Genes Dev. 2018, 32, 639-644. [CrossRef]

55. Zhang, Y.; Zhang, X.-O.; Chen, T.; Xiang, J.-F.; Yin, Q.-F.; Xing, Y.-H.; Zhu, S.; Yang, L.; Chen, L.-L. Circular Intronic Long Noncoding RNAs. Mol. Cell 2013, 51, 792-806. [CrossRef]

56. Petkovic, S.; Müller, S. RNA circularization strategies in vivo and in vitro. Nucleic Acids Res. 2015, 43, 2454-2465. [CrossRef]

57. Altesha, M.; Ni, T.; Khan, A.; Liu, K.; Zheng, X. Circular RNA in cardiovascular disease. J. Cell. Physiol. 2018, 234, 5588-5600. [CrossRef]

58. Jeck, W.; Sharpless, N. Detecting and characterizing circular RNAs. Nat. Biotechnol. 2014, 32, 453-461. [CrossRef] [PubMed]

59. Jeck, W.R.; Sorrentino, J.A.; Wang, K.; Slevin, M.K.; Burd, C.E.; Liu, J.; Marzluff, W.F.; Sharpless, N.E. Circular RNAs are abundant, conserved, and associated with ALU repeats. RNA 2012, 19, 141-157. [CrossRef]

60. Glažar, P.; Papavasileiou, P.; Rajewsky, N. circBase: A database for circular RNAs. RNA 2014, 20, 1666-1670. [CrossRef]

61. Dong, R.; Ma, X.K.; Li, G.W.; Yang, L. Circpedia v2, An updated database for comprehensive circular rna annotation and ex-pression comparison. Genom. Proteom. Bioinform. 2018, 16, 226-233. [CrossRef] 
62. Zheng, L.-L.; Ling-Ling, Z.; Wu, J.; Sun, W.-J.; Liu, S.; Wang, Z.-L.; Zhou, H.; Yang, J.-H.; Qu, L.-H. deepBase v2.0: Identification, expression, evolution and function of small RNAs, LncRNAs and circular RNAs from deep-sequencing data. Nucleic Acids Res. 2015, 44, D196-D202. [CrossRef]

63. Tang, Z.; Li, X.; Zhao, J.; Qian, F.; Feng, C.; Li, Y.; Zhang, J.; Jiang, Y.; Yang, Y.; Wang, Q.; et al. TRCirc: A resource for transcriptional regulation information of circRNAs. Brief. Bioinform. 2018, 20, 2327-2333. [CrossRef] [PubMed]

64. Wu, S.-M.; Liu, H.; Huang, P.-J.; Chang, I.; Lee, C.-C.; Yang, C.-Y.; Tsai, W.-S.; Tan, B.C.-M. circlncRNAnet: An integrated web-based resource for mapping functional networks of long or circular forms of non-coding RNAs. GigaScience 2017, 7, 1-10. [CrossRef]

65. Li, J.H.; Liu, S.; Zhou, H.; Qu, L.H.; Yang, J.H. Starbase v2.0, Decoding mirna-cerna, mirna-ncrna and protein-rna interaction net-works from large-scale clip-seq data. Nucleic Acids Res. 2014, 42, D92-D97. [CrossRef] [PubMed]

66. Dudekula, D.; Panda, A.; Grammatikakis, I.; De, S.; Abdelmohsen, K.; Gorospe, M. CircInteractome: A web tool for exploring circular RNAs and their interacting proteins and microRNAs. RNA Biol. 2015, 13, 34-42. [CrossRef]

67. Liu, M.; Wang, Q.; Shen, J.; Yang, B.B.; Ding, X. Circbank: A comprehensive database for circRNA with standard nomenclature. RNA Biol. 2019, 16, 899-905. [CrossRef]

68. Chen, X.; Han, P.; Zhou, T.; Guo, X.; Song, X.; Li, Y. Circrnadb: A comprehensive database for human circular rnas with pro-tein-coding annotations. Sci. Rep. 2016, 6, 34985. [CrossRef]

69. Xia, S.; Feng, J.; Chen, K.; Ma, Y.; Gong, J.; Cai, F.; Jin, Y.; Gao, Y.; Xia, L.; Chang, H.; et al. Cscd: A database for can-cer-specific circular rnas. Nucleic Acids Res. 2018, 46, D925-D929. [CrossRef]

70. Hancock JMGhosal, S.; Das, S.; Sen, R.; Basak, P.; Chakrabarti, J. Circ2Traits: A comprehensive database for circular RNA potentially associated with disease and traits. Front. Genet. 2013, 4, 283.

71. Zhao, Z.; Wang, K.; Wu, F.; Wang, W.; Zhang, K.; Hu, H.; Liu, Y.; Jiang, T. Circrna disease: A manually curated database of experi-mentally supported circrna-disease associations. Cell Death Dis. 2018, 9, 475. [CrossRef]

72. Papatsirou, M.; Artemaki, P.; Karousi, P.; Scorilas, A.; Kontos, C. Circular RNAs: Emerging Regulators of the Major Signaling Pathways Involved in Cancer Progression. Cancers 2021, 13, 2744. [CrossRef]

73. Yang, Z.-G.; Awan, F.M.; Du, W.W.; Zeng, Y.; Lyu, J.; Wu, D.; Gupta, S.; Yang, W.; Yang, B.B. The Circular RNA Interacts with STAT3, Increasing Its Nuclear Translocation and Wound Repair by Modulating Dnmt3a and miR-17 Function. Mol. Ther. 2017, 25, 2062-2074. [CrossRef]

74. Qu, S.; Zhong, Y.; Shang, R.; Zhang, X.; Song, W.; Kjems, J.; Li, H. The emerging landscape of circular RNA in life processes. RNA Biol. 2016, 14, 992-999. [CrossRef] [PubMed]

75. Zhao, Z.-J.; Shen, J. Circular RNA participates in the carcinogenesis and the malignant behavior of cancer. RNA Biol. 2016, 14, 514-521. [CrossRef] [PubMed]

76. Yang, W.; Du, W.W.; Li, X.; Yee, A.J.; Yang, B.B. Foxo3 activity promoted by non-coding effects of circular RNA and Foxo3 pseudogene in the inhibition of tumor growth and angiogenesis. Oncogene 2015, 35, 3919-3931. [CrossRef]

77. Zhu, K.-P.; Zhang, C.-L.; Ma, X.-L.; Hu, J.-P.; Cai, T.; Zhang, L. Analyzing the Interactions of mRNAs and ncRNAs to Predict Competing Endogenous RNA Networks in Osteosarcoma Chemo-Resistance. Mol. Ther. 2019, 27, 518-530. [CrossRef] [PubMed]

78. Hansen, T.; Jensen, T.I.; Clausen, B.H.; Bramsen, J.B.; Finsen, B.; Damgaard, C.; Kjems, J. Natural RNA circles function as efficient microRNA sponges. Nature 2013, 495, 384-388. [CrossRef] [PubMed]

79. Ashwal-Fluss, R.; Meyer, M.; Pamudurti, N.R.; Ivanov, A.; Bartok, O.; Hanan, M.; Evantal, N.; Memczak, S.; Rajewsky, N.; Kadener, S. Circrna biogenesis competes with pre-mrna splicing. Mol. Cell. 2014, 56, 55-66. [CrossRef] [PubMed]

80. Wesselhoeft, R.A.; Kowalski, P.; Anderson, D.G. Engineering circular RNA for potent and stable translation in eukaryotic cells. Nat. Commun. 2018, 9, 1-10. [CrossRef]

81. Zhang, M.; Huang, N.; Yang, X.; Luo, J.; Yan, S.; Xiao, F.; Chen, W.; Gao, X.; Zhao, K.; Zhou, H.; et al. A novel protein encoded by the circular form of the SHPRH gene suppresses glioma tumorigenesis. Oncogene 2018, 37, 1805-1814. [CrossRef]

82. Li, F.; Yang, Q.; He, A.T.; Yang, B.B. Circular RNAs in cancer: Limitations in functional studies and diagnostic potential. Semin. Cancer Biol. 2020, in press. [CrossRef]

83. Guarnerio, J.; Bezzi, M.; Jeong, J.C.; Paffenholz, S.V.; Berry, K.; Naldini, M.M.; Lo-Coco, F.; Tay, Y.; Beck, A.H.; Pandolfi, P.P. Oncogenic role of fusion-circrnas derived from cancer-associated chromosomal translocations. Cell 2016, 166, 1055-1056. [CrossRef] [PubMed]

84. Wu, K.; Liao, X.; Gong, Y.; He, J.; Zhou, J.K.; Tan, S.; Pu, W.; Huang, C.; Wei, Y.Q.; Peng, Y. Circular rna f-circsr derived from slc34a2-ros1 fusion gene promotes cell migration in non-small cell lung cancer. Mol. Cancer 2019, 18, 98. [CrossRef] [PubMed]

85. Gao, X.; Xia, X.; Li, F.; Zhang, M.; Zhou, H.; Wu, X.; Zhong, J.; Zhao, Z.; Zhao, K.; Liu, D.; et al. Circular RNA-encoded oncogenic E-cadherin variant promotes glioblastoma tumorigenicity through activation of EGFR-STAT3 signalling. Nature 2021, 23, 278-291. [CrossRef]

86. Ma, J.; Du, W.W.; Zeng, K.; Wu, N.; Fang, L.; Lyu, J.; Yee, A.J.; Yang, B.B. An antisense circular RNA circSCRIB enhances cancer progression by suppressing parental gene splicing and translation. Mol. Ther. 2021, 29, 2754-2768. [CrossRef]

87. Li, F.; Yang, B.B. Non-coding rnas in invadopodia: New insights into cancer metastasis. Front. Oncol. 2021, 11, 681576. [CrossRef]

88. Fang, L.; Du, W.W.; Awan, F.M.; Dong, J.; Yang, B.B. The circular RNA circ-Ccnb1 dissociates Ccnb1/Cdk1 complex suppressing cell invasion and tumorigenesis. Cancer Lett. 2019, 459, 216-226. [CrossRef] 
89. Wu, N.; Xu, J.; Du, W.W.; Li, X.; Awan, F.M.; Li, F.; Misir, S.; Eshaghi, E.; Lyu, J.; Zhou, L.; et al. YAP Circular RNA, circYap, Attenuates Cardiac Fibrosis via Binding with Tropomyosin-4 and Gamma-Actin Decreasing Actin Polymerization. Mol. Ther. 2021, 29, 1138-1150. [CrossRef] [PubMed]

90. Zeng, Y.; Du, W.W.; Wu, Y.; Yang, Z.; Awan, F.M.; Li, X.; Yang, W.; Zhang, C.; Yang, Q.; Yee, A.J.; et al. A Circular RNA Binds To and Activates AKT Phosphorylation and Nuclear Localization Reducing Apoptosis and Enhancing Cardiac Repair. Theranostics 2017, 7, 3842-3855. [CrossRef]

91. Zhang, C.; Huo, S.T.; Wu, Z.; Chen, L.; Wen, C.; Chen, H.; Du, W.W.; Wu, N.; Guan, D.; Lian, S.; et al. Rapid Development of Targeting circRNAs in Cardiovascular Diseases. Mol. Ther. Nucleic Acids 2020, 21, 568-576. [CrossRef] [PubMed]

92. Yang, L.; Han, B.; Zhang, Z.; Wang, S.; Bai, Y.; Zhang, Y.; Tang, Y.; Du, L.; Xu, L.; Wu, F.; et al. Extracellular Vesicle-Mediated Delivery of Circular RNA SCMH1 Promotes Functional Recovery in Rodent and Nonhuman Primate Ischemic Stroke Models. Circulation 2020, 142, 556-574. [CrossRef]

93. Wu, F.; Han, B.; Wu, S.; Yang, L.; Leng, S.; Li, M.; Liao, J.; Wang, G.; Ye, Q.; Zhang, Y.; et al. Circular RNA TLK1 Aggravates Neuronal Injury and Neurological Deficits after Ischemic Stroke via miR-335-3p/TIPARP. J. Neurosci. 2019, 39, 7369-7393. [CrossRef]

94. Yang, L.; Han, B.; Zhang, Y.; Bai, Y.; Chao, J.; Hu, G.; Yao, H. Engagement of circular RNA HECW2 in the nonautophagic role of ATG5 implicated in the endothelial-mesenchymal transition. Autophagy 2018, 14, 404-418. [CrossRef]

95. Diling, C.; Longkai, Q.; Yinrui, G.; Yadi, L.; Xiaocui, T.; Xiangxiang, Z.; Miao, Z.; Ran, L.; Ou, S.; Dongdong, W.; et al. CircNF1-419 improves the gut microbiome structure and function in AD-like mice. Aging 2020, 12, 260-287. [CrossRef]

96. Awan, F.M.; Yang, B.B.; Naz, A.; Hanif, A.; Ikram, A.; Obaid, A.; Malik, A.; Janjua, H.A.; Ali, A.; Sharif, S. The emerging role and signif-icance of circular rnas in viral infections and antiviral immune responses: Possible implication as theranostic agents. RNA Biol. 2021, 18, 1-15. [CrossRef] [PubMed]

97. Yang, Q.; Li, F.; He, A.T.; Yang, B.B. Circular rnas: Expression, localization, and therapeutic potentials. Mol. Ther. J. Am. Soc. Gene Ther. 2021, 29, 1683-1702. [CrossRef]

98. Du, W.W.; Yang, W.; Liu, E.; Yang, Z.; Dhaliwal, P.; Yang, B.B. Foxo3 circular RNA retards cell cycle progression via forming ternary complexes with p21 and CDK2. Nucleic Acids Res. 2016, 44, 2846-2858. [CrossRef]

99. Diling, C.; Yinrui, G.; Longkai, Q.; Xiaocui, T.; Yadi, L.; Xin, Y.; Guoyan, H.; Ou, S.; Tianqiao, Y.; Dongdong, W.; et al. Circular RNA NF1-419 enhances autophagy to ameliorate senile dementia by binding Dynamin-1 and Adaptor protein 2 B1 in AD-like mice. Aging 2019, 11, 12002-12031. [CrossRef] [PubMed]

100. Wu, N.; Yuan, Z.; Du, K.Y.; Fang, L.; Lyu, J.; Zhang, C.; He, A.; Eshaghi, E.; Zeng, K.; Ma, J.; et al. Translation of yes-associated protein (YAP) was antagonized by its circular RNA via suppressing the assembly of the translation initiation machinery. Cell Death Differ. 2019, 26, 2758-2773. [CrossRef]

101. Zhou, Z.-B.; Huang, G.-X.; Fu, Q.; Han, B.; Lu, J.-J.; Chen, A.-M.; Zhu, L. circRNA.33186 Contributes to the Pathogenesis of Osteoarthritis by Sponging miR-127-5p. Mol. Ther. 2019, 27, 531-541. [CrossRef]

102. Li, W.; Li, Y.; Sun, Z.; Zhou, J.; Cao, Y.; Ma, W.; Xie, K.; Yan, X. Comprehensive circular RNA profiling reveals the regulatory role of the hsa_circ_0137606/miR-1231 pathway in bladder cancer progression. Int. J. Mol. Med. 2019, 44, 1719-1728. [CrossRef] [PubMed]

103. Li, S.; Zhao, Y.; Chen, X. Microarray expression profile analysis of circular RNAs and their potential regulatory role in bladder carcinoma. Oncol. Rep. 2020, 45, 239-253. [CrossRef] [PubMed]

104. Yang, C.; Li, Q.; Chen, X.; Zhang, Z.; Mou, Z.; Ye, F.; Jin, S.; Jun, X.; Tang, F.; Jiang, H. Circular RNA circRGNEF promotes bladder cancer progression via miR-548/KIF2C axis regulation. Aging 2020, 12, 6865-6879. [CrossRef] [PubMed]

105. Su, Y.; Feng, W.; Shi, J.; Chen, L.; Huang, J.; Lin, T. Circrip2 accelerates bladder cancer progression via mir-1305/tgf-beta2/smad3 pathway. Mol. Cancer 2020, 19, 23. [CrossRef]

106. Mao, W.; Huang, X.; Wang, L.; Zhang, Z.; Liu, M.; Li, Y.; Luo, M.; Yao, X.; Fan, J.; Geng, J. Circular RNA hsa_circ_0068871 regulates FGFR3 expression and activates STAT3 by targeting miR-181a-5p to promote bladder cancer progression. J. Exp. Clin. Cancer Res. 2019, 38, 1-14. [CrossRef] [PubMed]

107. Wu, Z.; Huang, W.; Wang, X.; Wang, T.; Chen, Y.; Chen, B.; Liu, R.; Bai, P.; Xing, J. Circular RNA CEP128 acts as a sponge of miR-145-5p in promoting the bladder cancer progression via regulating SOX11. Mol. Med. 2018, 24, 1-13. [CrossRef]

108. Liu, P.; Li, X.; Guo, X.; Chen, J.; Li, C.; Chen, M.; Liu, L.; Zhang, X.; Zu, X. Circular rna dock1 promotes bladder carcinoma progression via modulating circdock1/hsa-mir-132-3p/sox5 signalling pathway. Cell Prolif. 2019, 52, e12614. [CrossRef] [PubMed]

109. Chen, Q.; Yin, Q.; Mao, Y.; Zhang, Z.; Wu, S.; Cheng, Z.; Chen, X.; Xu, H.; Jin, S.; Jiang, H.; et al. Hsa_circ_0068307 mediates bladder cancer stem cell-like properties via miR-147/c-Myc axis regulation. Cancer Cell Int. 2020, 20, 1-10. [CrossRef]

110. Chen, L.; Yang, X.; Zhao, J.; Xiong, M.; Almaraihah, R.; Chen, Z.; Hou, T. Circ_0008532 promotes bladder cancer progression by regulation of the miR-155-5p/miR-330-5p/MTGR1 axis. J. Exp. Clin. Cancer Res. 2020, 39, 1-12. [CrossRef]

111. Li, Y.; Qiao, L.; Zang, Y.; Ni, W.; Xu, Z. Circular RNA FOXO3 Suppresses Bladder Cancer Progression and Metastasis by Regulating MiR-9-5p/TGFBR2. Cancer Manag. Res. 2020, 12, 5049-5056. [CrossRef] [PubMed]

112. Wang, C.; Tao, W.; Ni, S.; Chen, Q. Circular RNA circ-Foxo3 induced cell apoptosis in urothelial carcinoma via interaction with miR-191-5p. OncoTargets Ther. 2019, 12, 8085-8094. [CrossRef]

113. Xie, F.; Li, Y.; Wang, M.; Huang, C.; Tao, D.; Zheng, F.; Zhang, H.; Zeng, F.; Xiao, X.; Jiang, G. Circular RNA BCRC-3 suppresses bladder cancer proliferation through miR-182-5p/p27 axis. Mol. Cancer 2018, 17, 1-12. [CrossRef] 
114. Li, P.; Yang, X.; Yuan, W.; Yang, C.; Zhang, X.; Han, J.; Wang, J.; Deng, X.; Yang, H.; Li, P.; et al. Circrna-cdr1as exerts anti-oncogenic functions in bladder cancer by sponging microrna-135a. Cell Physiol. Biochem. 2018, 46, 1606-1616. [CrossRef]

115. Zheng, F.; Wang, M.; Li, Y.; Huang, C.; Tao, D.; Xie, F.; Zhang, H.; Sun, J.; Zhang, C.; Gu, C.; et al. Circnr3c1 inhibits pro-liferation of bladder cancer cells by sponging mir-27a-3p and downregulating cyclin d1 expression. Cancer Lett. 2019, 460, 139-151. [CrossRef]

116. He, Q.; Huang, L.; Yan, D.; Bi, J.; Yang, M.; Huang, J.; Lin, T. CircPTPRA acts as a tumor suppressor in bladder cancer by sponging miR-636 and upregulating KLF9. Aging 2019, 11, 11314-11328. [CrossRef] [PubMed]

117. Lu, Q.; Liu, T.; Feng, H.; Yang, R.; Zhao, X.; Chen, W.; Jiang, B.; Qin, H.; Guo, X.; Liu, M.; et al. Circular RNA circSLC8A1 acts as a sponge of miR-130b/miR-494 in suppressing bladder cancer progression via regulating PTEN. Mol. Cancer 2019, 18, 1-13. [CrossRef] [PubMed]

118. Yang, C.; Yuan, W.; Yang, X.; Li, P.; Wang, J.; Han, J.; Tao, J.; Li, P.; Yang, H.; Lv, Q.; et al. Circular RNA circ-ITCH inhibits bladder cancer progression by sponging miR-17/miR-224 and regulating p21, PTEN expression. Mol. Cancer 2018, 17, 19. [CrossRef]

119. Li, B.; Xie, F.; Zheng, F.X.; Jiang, G.S.; Zeng, F.Q.; Xiao, X.Y. Overexpression of circrna bcrc4 regulates cell apoptosis and mi-crorna-101/ezh2 signaling in bladder cancer. J. Huazhong Univ. Sci. Technol. Med. Sci. 2017, 37, 886-890.

120. Yang, D.; Qian, H.; Fang, Z.; Xu, A.; Zhao, S.; Liu, B.; Li, D. Silencing circular RNA VANGL1 inhibits progression of bladder cancer by regulating miR-1184/IGFBP2 axis. Cancer Med. 2019, 9, 700-710. [CrossRef]

121. Zeng, Z.; Zhou, W.; Duan, L.; Zhang, J.; Lu, X.; Jin, L.; Yu, Y. Circular RNA circ-VANGL1 as a competing endogenous RNA contributes to bladder cancer progression by regulating miR-605-3p/VANGL1 pathway. J. Cell. Physiol. 2018, 234, 3887-3896. [CrossRef]

122. Sun, M.; Zhao, W.; Chen, Z.; Li, M.; Li, S.; Wu, B.; Bu, R. Circular RNA CEP128 promotes bladder cancer progression by regulating Mir-145-5p/ Myd88 via MAPK signaling pathway. Int. J. Cancer 2019, 145, 2170-2181. [CrossRef]

123. Sun, M.; Zhao, W.; Chen, Z.; Li, M.; Li, S.; Wu, B.; Bu, R. Circ_0058063 regulates CDK6 to promote bladder cancer progression by sponging miR-145-5p. J. Cell. Physiol. 2018, 234, 4812-4824. [CrossRef] [PubMed]

124. Liang, H.; Huang, H.; Li, Y.; Lu, Y.; Ye, T. CircRNA_0058063 functions as a ceRNA in bladder cancer progression via targeting miR-486-3p/FOXP4 axis. Biosci. Rep. 2020, 40. [CrossRef]

125. Zhong, Z.; Lv, M.; Chen, J. Screening differential circular RNA expression profiles reveals the regulatory role of circTCF25-miR103a-3p/miR-107-CDK6 pathway in bladder carcinoma. Sci. Rep. 2016, 6, 30919. [CrossRef] [PubMed]

126. Su, H.; Tao, T.; Yang, Z.; Kang, X.; Zhang, X.; Kang, D.; Wu, S.; Li, C. Circular RNA cTFRC acts as the sponge of MicroRNA-107 to promote bladder carcinoma progression. Mol. Cancer 2019, 18, 1-15. [CrossRef] [PubMed]

127. Zhang, X.; Liu, X.; Jing, Z.; Bi, J.; Li, Z.; Liu, X.; Li, J.; Li, Z.; Zhang, Z.; Kong, C. The circints4/mir-146b/carma3 axis promotes tumor-igenesis in bladder cancer. Cancer Gene Ther. 2020, 27, 189-202. [CrossRef]

128. Shi, Y.R.; Wu, Z.; Xiong, K.; Liao, Q.J.; Ye, X.; Yang, P.; Zu, X.B. Circular rna circkif4a sponges mir-375/1231 to promote bladder cancer progression by upregulating notch2 expression. Front. Pharmacol. 2020, 11, 605. [CrossRef] [PubMed]

129. Abulizi, R.; Li, B.; Zhang, C.G. Circ_0071662, a novel tumor biomarker, suppresses bladder cancer cell proliferation and invasion by sponging mir-146b-3p. Oncol. Res. 2019. [CrossRef]

130. Liu, T.; Lu, Q.; Liu, J.; Xie, S.; Feng, B.; Zhu, W.; Liu, M.; Liu, Y.; Zhou, X.; Sun, W.; et al. Circular RNA FAM114A2 suppresses progression of bladder cancer via regulating $\triangle \mathrm{NP63}$ by sponging miR-762. Cell Death Dis. 2020, 11, 1-14. [CrossRef]

131. Zhang, L.; Xia, H.-B.; Zhao, C.-Y.; Shi, L.; Ren, X.-L. Cyclic RNA hsa_circ_0091017 inhibits proliferation, migration and invasiveness of bladder cancer cells by binding to microRNA-589-5p. Eur. Rev. Med. Pharmacol. Sci. 2020, 24, 86-96. [PubMed]

132. Jiang, Y.; Wei, T.; Li, W.; Zhang, R.; Chen, M. Circular RNA hsa_circ_0002024 suppresses cell proliferation, migration, and invasion in bladder cancer by sponging miR-197-3p. Am. J. Transl. Res. 2019, 11, 1644-1652.

133. Liu, H.; Chen, D.; Bi, J.; Han, J.; Yang, M.; Dong, W.; Lin, T.; Huang, J. Circular RNA circUBXN7 represses cell growth and invasion by sponging miR-1247-3p to enhance B4GALT3 expression in bladder cancer. Aging 2018, 10, 2606-2623. [CrossRef]

134. Zeng, K.; He, B.; Yang, B.B.; Xu, T.; Chen, X.; Xu, M.; Liu, X.; Sun, H.; Pan, Y.; Wang, S. The pro-metastasis effect of circANKS1B in breast cancer. Mol. Cancer 2018, 17, 1-19. [CrossRef]

135. Wu, L.; Zhang, M.; Qi, L.; Zu, X.; Li, Y.; Liu, L.; Chen, M.; Li, Y.; He, W.; Hu, X.; et al. Eralpha-mediated alterations in circ_0023642 and mir-490-5p signaling suppress bladder cancer invasion. Cell Death Dis. 2019, 10, 635. [CrossRef] [PubMed]

136. Xie, F.; Huang, C.; Liu, F.; Zhang, H.; Xiao, X.; Sun, J.; Zhang, X.; Jiang, G. CircPTPRA blocks the recognition of RNA N6-methyladenosine through interacting with IGF2BP1 to suppress bladder cancer progression. Mol. Cancer 2021, $20,1-17$. [CrossRef] [PubMed]

137. Li, M.; Liu, Y.; Liu, J.; Li, W.; Li, N.; Xue, D.; Zhang, X.; Wang, P. Circ_0006332 promotes growth and progression of bladder cancer by modulating MYBL2 expression via miR-143. Aging 2019, 11, 10626-10643. [CrossRef] [PubMed]

138. Chen, X.; Chen, R.X.; Wei, W.S.; Li, Y.H.; Feng, Z.H.; Tan, L.; Chen, J.W.; Yuan, G.J.; Chen, S.L.; Guo, S.J.; et al. Prmt5 circular rna promotes metastasis of urothelial carcinoma of the bladder through sponging mir-30c to induce epithe-lial-mesenchymal transition. Clin. Cancer Res. 2018, 24, 6319-6330. [CrossRef] [PubMed]

139. Zhong, Z.; Huang, M.; Lv, M.; He, Y.; Duan, C.; Zhang, L.; Chen, J. Circular RNA MYLK as a competing endogenous RNA promotes bladder cancer progression through modulating VEGFA/VEGFR2 signaling pathway. Cancer Lett. 2017, 403, 305-317. [CrossRef] 
140. Tong, L.; Yang, H.; Xiong, W.; Tang, G.; Zu, X.; Qi, L. Circ_100984-mir-432-3p axis regulated c-jun/ybx-1/beta-catenin feedback loop promotes bladder cancer progression. Cancer Sci. 2021, 112, 1429-1442. [CrossRef]

141. Yang, C.; Mou, Z.; Zhang, Z.; Wu, S.; Zhou, Q.; Chen, Y.; Gong, J.; Xu, C.; Ou, Y.; Chen, X.; et al. Circular RNA RBPMS inhibits bladder cancer progression via miR-330-3p/RAI2 regulation. Mol. Ther. Nucleic Acids 2021, 23, 872-886. [CrossRef]

142. Tan, S.; Kang, Y.; Li, H.; He, H.-Q.; Zheng, L.; Wu, S.-Q.; Ai, K.; Zhang, L.; Xu, R.; Zhang, X.-Z.; et al. circST6GALNAC6 suppresses bladder cancer metastasis by sponging miR-200a-3p to modulate the STMN1/EMT axis. Cell Death Dis. 2021, 12, 1-15. [CrossRef]

143. Wang, J.; Luo, J.; Wu, X.; Gao, Z. Circular RNA_0000629 Suppresses Bladder Cancer Progression Mediating MicroRNA1290/CDC73. Cancer Manag. Res. 2021, 13, 2701-2715. [CrossRef]

144. Yan, D.; Dong, W.; He, Q.; Yang, M.; Huang, L.; Kong, J.; Qin, H.; Lin, T.; Huang, J. Circular RNA circPICALM sponges miR-1265 to inhibit bladder cancer metastasis and influence FAK phosphorylation. EBioMedicine 2019, 48, 316-331. [CrossRef]

145. Liu, H.; Bi, J.; Dong, W.; Yang, M.; Shi, J.; Jiang, N.; Lin, T.; Huang, J. Invasion-related circular RNA circFNDC3B inhibits bladder cancer progression through the miR-1178-3p/G3BP2/SRC/FAK axis. Mol. Cancer 2018, 17, 1-19. [CrossRef] [PubMed]

146. Dongre, A.; Weinberg, R.A. New insights into the mechanisms of epithelial-mesenchymal transition and implications for cancer. Nat. Rev. Mol. Cell Biol. 2019, 20, 69-84. [CrossRef]

147. Rodriguez-Aznar, E.; Wiesmuller, L.; Sainz, B., Jr.; Hermann, P.C. Emt and stemness-key players in pancreatic cancer stem cells. Cancers 2019, 11, 1136. [CrossRef] [PubMed]

148. Wei, G.Y.; Hu, M.; Zhao, L.; Guo, W.S. Mir-451a suppresses cell proliferation, metastasis and emt via targeting ywhaz in hepato-cellular carcinoma. Eur. Rev. Med. Pharmacol. Sci. 2019, 23, 5158-5167. [PubMed]

149. Rodriguez, R.H.M.; Rueda, O.B.; Ibarz, L. Bladder cancer: Present and future. Med. Clin. 2017, 149, 449-455. [CrossRef]

150. Papatsirou, M.; Artemaki, P.I.; Scorilas, A.; Kontos, C.K. The role of circular RNAs in therapy resistance of patients with solid tumors. Pers. Med. 2020, 17, 469-490. [CrossRef] [PubMed]

151. Xu, T.; Wang, M.; Jiang, L.; Ma, L.; Wan, L.; Chen, Q.; Wei, C.; Wang, Z. CircRNAs in anticancer drug resistance: Recent advances and future potential. Mol. Cancer 2020, 19, 1-20. [CrossRef] [PubMed]

152. Ma, S.; Kong, S.; Wang, F.; Ju, S. CircRNAs: Biogenesis, functions, and role in drug-resistant Tumours. Mol. Cancer 2020, 19, 1-19. [CrossRef]

153. He, A.T.; Liu, J.; Li, F.; Yang, B.B. Targeting circular RNAs as a therapeutic approach: Current strategies and challenges. Signal Transduct. Target. Ther. 2021, 6, 1-14. [CrossRef]

154. Santer, L.; Bär, C.; Thum, T. Circular RNAs: A Novel Class of Functional RNA Molecules with a Therapeutic Perspective. Mol. Ther. 2019, 27, 1350-1363. [CrossRef]

155. Yuan, W.; Zhou, R.; Wang, J.; Han, J.; Yang, X.; Yu, H.; Lu, H.; Zhang, X.; Li, P.; Tao, J.; et al. Circular RNA Cdr1as sensitizes bladder cancer to cisplatin by upregulating APAF1 expression through miR-1270 inhibition. Mol. Oncol. 2019, 13, 1559-1576. [CrossRef]

156. Xie, F.; Zhao, N.; Zhang, H.; Xie, D. Circular RNA CircHIPK3 Promotes Gemcitabine Sensitivity in Bladder Cancer. J. Cancer 2020, 11, 1907-1912. [CrossRef] [PubMed]

157. Su, Y.; Yang, W.; Jiang, N.; Shi, J.; Chen, L.; Zhong, G.; Bi, J.; Dong, W.; Wang, Q.; Wang, C.; et al. Hypoxia-elevated circELP3 contributes to bladder cancer progression and cisplatin resistance. Int. J. Biol. Sci. 2019, 15, 441-452. [CrossRef]

158. Chen, J.; Sun, Y.; Ou, Z.; Yeh, S.; Huang, C.P.; You, B.; Tsai, Y.C.; Sheu, T.J.; Zu, X.; Chang, C. Androgen receptor-regulated circfnta ac-tivates kras signaling to promote bladder cancer invasion. EMBO Rep. 2020, 21, e48467. [CrossRef]

159. Gong, P.; Xu, R.; Zhuang, Q.; He, X. A novel circular RNA (hsa_circRNA_102336), a plausible biomarker, promotes the tumorigenesis by sponging miR-515-5p in human bladder cancer. Biomed. Pharmacother. 2020, 126, 110059. [CrossRef] [PubMed]

160. Chi, B.J.; Zhao, D.M.; Liu, L.; Yin, X.Z.; Wang, F.F.; Bi, S.; Gui, S.L.; Zhou, S.; Qin, W.B.; Wu, D.M.; et al. Downregulation of hsa_circ_0000285 serves as a prognostic biomarker for bladder cancer and is involved in cisplatin resistance. Neoplasma 2019, 66, 197-202. [CrossRef] [PubMed]

161. Huang, W.; Lu, Y.; Wang, F.; Huang, X.; Yu, Z. Circular RNA circRNA_103809 Accelerates Bladder Cancer Progression and Enhances Chemo-Resistance by Activation of miR-516a-5p/FBXL18 Axis. Cancer Manag. Res. 2020, 12, 7561-7568. [CrossRef]

162. Liu, Q.; Zhou, Q.; Zhong, P. Circ_0067934 increases bladder cancer cell proliferation, migration and invasion through sup-pressing mir-1304 expression and increasing myc expression levels. Exp. Ther. Med. 2020, 19, 3751-3759.

163. Tang, G.; Xie, W.; Qin, C.; Zhen, Y.; Wang, Y.; Chen, F.; Du, Z.; Wu, Z.; Zhang, B.; Shen, Z.; et al. Expression of circular RNA circASXL1 correlates with TNM classification and predicts overall survival in bladder cancer. Int. J. Clin. Exp. Pathol. 2017, 10, 8495-8502.

164. Gu, C.; Zhou, N.; Wang, Z.; Li, G.; Kou, Y.; Yu, S.; Feng, Y.; Chen, L.; Yang, J.; Tian, F. circGprc5a Promoted Bladder Oncogenesis and Metastasis through Gprc5a-Targeting Peptide. Mol. Ther. Nucleic Acids 2018, 13, 633-641. [CrossRef]

165. Liu, F.; Zhang, H.; Xie, F.; Tao, D.; Xiao, X.; Huang, C.; Wang, M.; Gu, C.; Zhang, X.; Jiang, G. Hsa_circ_0001361 promotes bladder cancer invasion and metastasis through miR-491-5p/MMP9 axis. Oncogene 2019, 39, 1696-1709. [CrossRef]

166. Li, Y.; Wan, B.; Liu, L.; Zhou, L.; Zeng, Q. Circular RNA circMTO1 suppresses bladder cancer metastasis by sponging miR-221 and inhibiting epithelial-to-mesenchymal transition. Biochem. Biophys. Res. Commun. 2018, 508, 991-996. [CrossRef] [PubMed]

167. Lin, G.; Sheng, H.; Xie, H.; Zheng, Q.; Shen, Y.; Shi, G.; Ye, D. circLPAR1 is a novel biomarker of prognosis for muscle-invasive bladder cancer with invasion and metastasis by miR-762. Oncol. Lett. 2019, 17, 3537-3547. [CrossRef] [PubMed] 
168. Dong, W.; Bi, J.; Liu, H.; Yan, D.; He, Q.; Zhou, Q.; Wang, Q.; Xie, R.; Su, Y.; Yang, M.; et al. Circular RNA ACVR2A suppresses bladder cancer cells proliferation and metastasis through miR-626/EYA4 axis. Mol. Cancer 2019, 18, 1-16. [CrossRef] [PubMed]

169. Zhang, W.-Y.; Liu, Q.-H.; Wang, T.-J.; Zhao, J.; Cheng, X.-H.; Wang, J.-S. CircZFR serves as a prognostic marker to promote bladder cancer progression by regulating miR-377/ZEB2 signaling. Biosci. Rep. 2019, 39. [CrossRef]

170. He, Q.; Yan, D.; Dong, W.; Bi, J.; Huang, L.; Yang, M.; Huang, J.; Qin, H.; Lin, T. circRNA circFUT8 Upregulates Krüpple-like Factor 10 to Inhibit the Metastasis of Bladder Cancer via Sponging miR-570-3p. Mol. Ther. Oncolytics 2020, 16, 172-187. [CrossRef] [PubMed]

171. Bi, J.; Liu, H.; Dong, W.; Xie, W.; He, Q.; Cai, Z.; Huang, J.; Lin, T. Circular RNA circ-ZKSCAN1 inhibits bladder cancer progression through miR-1178-3p/p21 axis and acts as a prognostic factor of recurrence. Mol. Cancer 2019, 18, 1-14. [CrossRef] [PubMed]

172. Li, M.; Wang, Y.; Liu, Y.; Zhang, X.; Liu, J.; Wang, P. Low Expression of hsa_circ_0018069 in Human Bladder Cancer and Its Clinical Significance. BioMed Res. Int. 2019, 2019, 1-9. [CrossRef] [PubMed]

173. Wang, H.; Niu, X.; Mao, F.; Liu, X.; Zhong, B.; Jiang, H.; Fu, G. Hsa_circRNA_100146 Acts as a Sponge of miR-149-5p in Promoting Bladder Cancer Progression via Regulating RNF2. OncoTargets Ther. 2020, 13, 11007-11017. [CrossRef] [PubMed]

174. Yang, Q.; Du, W.W.; Wu, N.; Yang, W.; Awan, F.M.; Fang, L.; Ma, J.; Li, X.; Zeng, Y.; Yang, Z.; et al. A circular RNA promotes tumorigenesis by inducing c-myc nuclear translocation. Cell Death Differ. 2017, 24, 1609-1620. [CrossRef]

175. Song, Z.; Zhang, Q.; Zhu, J.; Yin, G.; Lin, L.; Liang, C. Identification of urinary hsa_circ_0137439 as a potential biomarker and tumor regulator of bladder cancer. Neoplasma 2020, 67, 137-146. [CrossRef] [PubMed]

176. Bi, J.; Liu, H.; Cai, Z.; Dong, W.; Jiang, N.; Yang, M.; Huang, J.; Lin, T. Circ-BPTF promotes bladder cancer progression and recurrence through the miR-31-5p/RAB27A axis. Aging 2018, 10, 1964-1976. [CrossRef]

177. Liu, Z.; Yang, Y.; Yang, Z.; Xia, S.; Lin, D.; Xiao, B.; Xiu, Y. Novel circrna_0071196/mirna19b3p/cit axis is associated with proliferation and migration of bladder cancer. Int. J. Oncol. 2020, 57, 767-779. [CrossRef]

178. Xu, Z.; Yang, M.; Liu, H.; Su, C. Circular RNA hsa_circ_0003221 (circPTK2) promotes the proliferation and migration of bladder cancer cells. J. Cell. Biochem. 2017, 119, 3317-3325. [CrossRef]

179. Wang, L.; Li, H.; Qiao, Q.; Ge, Y.; Ma, L.; Wang, Q. Circular RNA circSEMA5A promotes bladder cancer progression by upregulating ENO1 and SEMA5A expression. Aging 2020, 12, 21674-21686. [CrossRef] [PubMed]

180. Su, Y.; Feng, W.; Zhong, G.; Ya, Y.; Du, Z.; Shi, J.; Chen, L.; Dong, W.; Lin, T. ciRs-6 upregulates March1 to suppress bladder cancer growth by sponging miR-653. Aging 2019, 11, 11202-11223. [CrossRef]

181. Shen, C.; Wu, Z.; Wang, Y.; Gao, S.; Da, L.; Xie, L.; Hu, H. Downregulated hsa_circ_0077837 and hsa_circ_0004826, facilitate bladder cancer progression and predict poor prognosis for bladder cancer patients. Cancer Med. 2020, 9, 3885-3903. [CrossRef]

182. Sun, J.; Zhang, H.; Tao, D.; Xie, F.; Liu, F.; Gu, C.; Wang, M.; Wang, L.; Jiang, G.; Wang, Z.; et al. CircCDYL inhibits the expression of C-MYC to suppress cell growth and migration in bladder cancer. Artif. Cells Nanomed. Biotechnol. 2019, 47, 1349-1356. [CrossRef]

183. Panda, A.; De, S.; Grammatikakis, I.; Munk, R.; Yang, X.; Piao, Y.; Dudekula, D.B.; Abdelmohsen, K.; Gorospe, M. High-purity circular RNA isolation method (RPAD) reveals vast collection of intronic circRNAs. Nucleic Acids Res. 2017, 45, e116. [CrossRef] [PubMed]

184. Kristensen, L.S.; Hansen, T.; Venø, M.T.; Kjems, J. Circular RNAs in cancer: Opportunities and challenges in the field. Oncogene 2017, 37, 555-565. [CrossRef] [PubMed]

185. Salzman, J.; Gawad, C.; Wang, P.L.; Lacayo, N.; Brown, P.O. Circular RNAs Are the Predominant Transcript Isoform from Hundreds of Human Genes in Diverse Cell Types. PLoS ONE 2012, 7, e30733. [CrossRef]

186. Rigatti, R.; Jia, J.-H.; Samani, N.J.; Eperon, I.C. Exon repetition: A major pathway for processing mRNA of some genes is allele-specific. Nucleic Acids Res. 2004, 32, 441-446. [CrossRef] [PubMed]

187. Chen, S.; Zhao, Y. Circular RNAs: Characteristics, function, and role in human cancer. Histol. Histopathol. $2018,33,887-893$.

188. Han, B.; Chao, J.; Yao, H. Circular RNA and its mechanisms in disease: From the bench to the clinic. Pharmacol. Ther. 2018, 187, 31-44. [CrossRef] [PubMed]

189. Guo, J.U.; Agarwal, V.; Guo, H.; Bartel, D.P. Expanded identification and characterization of mammalian circular rnas. Genome Biol. 2014, 15, 409. [CrossRef]

190. Mármol, I.; Sánchez-De-Diego, C.; Dieste, A.P.; Cerrada, E.; Yoldi, M.J.R. Colorectal Carcinoma: A General Overview and Future Perspectives in Colorectal Cancer. Int. J. Mol. Sci. 2017, 18, 197. [CrossRef]

191. Liu, Y.C.; Li, J.R.; Sun, C.H.; Andrews, E.; Chao, R.F.; Lin, F.M.; Weng, S.L.; Hsu, S.D.; Huang, C.C.; Cheng, C.; et al. Circnet: A database of circular rnas derived from transcriptome sequencing data. Nucleic Acids Res. 2016, 44, D209-D215. [CrossRef] [PubMed]

192. Geiss, G.K.; Bumgarner, R.; Birditt, B.; Dahl, T.; Dowidar, N.; Dunaway, D.L.; Fell, H.P.; Ferree, S.; George, R.D.; Grogan, T.; et al. Direct multiplexed measurement of gene expression with color-coded probe pairs. Nat. Biotechnol. 2008, 26, 317-325. [CrossRef] [PubMed] 